\title{
Türkiye Ekonomisinde İhracat ve Gayri Safi Yurt İçi Hasıla Arasındaki Uzun Dönem İlişkisi
}

\author{
Atilla AYDIN $^{1 *}$
}

Geliş Tarihi/Received: 20.01.2021

Kabul Tarihi/Accepted: 14.02.2021

Araştırma Makalesi/Research Article

\section{ÖZET}

Türkiye ekonomisinde 1980 sonrasında yaşanan liberalleşme süreciyle birlikte büyüme modeli olarak ihracata dayalı büyüme modeli benimsenmiştir. 1980 yılına kadar bazı dönemler daha liberal, bazı dönemler daha devletçi ekonomi politikaları uygulanmıştır. İhracat politikaları da uygulanan ekonomik politikalara göre şekillenmiştir. 1980 öncesi son yirmi yıl ithal ikameci sanayileşme politikası izlenmiştir. Bu çalışmanın amacı, Türkiye ekonomisi için ihracat ile GSYİH arasındaki uzun dönem ilişkisini saptamaktır. Çalışmada Türkiye'nin 1923-2019 arasındaki GSYİH ve ihracat verileri ABD dolar1 olarak kullanılmıştır. Öncelikle, Türkiye'de tarih boyunca uygulanan iktisat politikaları çerçevesinde ihracatın gelişimi incelenmiş ve GSYİH ile ihracat arasındaki ilişkinin ipuçları aranmıştır. Analiz bölümünde ise ekonometrik çalışma yapılmış ve ihracat ile GSYİH arasında bir uzun dönem ilişki bulunmamıştır. İhracatın ekonomik büyüme kaynağından çok ithalatın finansmanı açısından önemli bir iktisadi değişken olarak ele alınması, bu çalışmanın önemli bir çıktısını oluşturmaktadır.

Anahtar Kelimeler: İhracat, Gayri Safi Yurt İçi Hasıla, Büyüme, Eşbütünleşme, Türkiye

\footnotetext{
${ }^{1}$ Öğr. Gör., İstanbul Gelişim Üniversitesi, İstanbul Gelişim Meslek Yüksekokulu, , Hava Lojistiği Bölümü, Orcid No: 0000-0002-9265-5930

* Sorumlu yazar/Corresponding author

E-mail/e-ileti: ataydin@gelisim.edu.tr
} 


\title{
Long Term Relationship Between Exports and Gross Domestic Product in Turkish Economy
}

\begin{abstract}
Turkey's economy experienced in 1980 after the liberalization of export-oriented growth model has been adopted as a growth model with the process. Until 1980, more liberal and statist economic policies were implemented in some periods. Export policies are also shaped according to the economic policies applied. For the last twenty years before 1980, an import substitution industrialization policy was followed. The aim of this study was to determine Turkey's economy with exports for the long-term relationship between GDP. Working in Turkey's GDP and export data between 1923-2019 was used as the US dollar. First, examined the development of exports in the framework of the economic policies implemented in Turkey and throughout history have sought clues to the relationship between exports and GDP. In the analysis part, an econometric study was conducted and no long-term relationship was found between exports and GDP. Considering exports as an important economic variable in terms of financing imports rather than a source of economic growth constitutes an important output of this study.
\end{abstract}

Keywords: Export, Gross Domestic Product, Growth, Cointegration, Turkey

\section{GİRIŞ}

Türkiye ekonomisinde 24 Ocak 1980 kararlarıyla başlayan liberalleşme sürecinin en önemli tezlerinden birisi ihracata dayalı büyüme modelidir. 1980 yılında ilan edilen 24 Ocak kararlarıyla ithal ikamesi politikası terk edilmiş, bunun yerine ihracata dayalı bir büyüme politikası kabul edilmiştir (Karluk, 2005:497). Dışa açılma ve ihracata dayalı büyüme süreci, esas olarak çok güçlü ihracat teşvikleri, düşen emek maliyetleri ve 1980 devalüasyonunun etkilerinin kaybolmasını önleyen döviz kuru politikaları aracılığıyla dış piyasalara girmek olarak algılanmıştır (Boratav, 2014: 154).

1980 öncesinde ise dönemlere göre çeşitli ekonomi politikaları uygulanmış, uygulanan ekonomi politikalarına göre dış ticaret şekillenmiştir. Bu çalışmada Türkiye ihracatı ile GSYİH arasındaki ilişki, 1923 yılından itibaren uygulanan ekonomik politikalar çerçevesinde incelenmiştir. Çalışmanın amacı, ihracatın GSYİH üzerindeki etkisini ortaya çıkarmaktır. 
Böylece 1980 sonrası benimsenen ihracata dayalı büyüme modelinin geçerliliğinin sınanması da amaçlanmıştır.

Çalışmanın girişten sonraki ikinci bölümünde, Türkiye ekonomisinde dönemler itibariyle uygulanan ekonomik politikalar açıklanmış ve bu politikaların GSYİH ve ihracat üzerindeki yansımaları incelenmiştir. Üçüncü bölümde, daha önce bu konuda yapılmış olan çalışmaları içeren bir literatür taraması yapılmıştır. Dördüncü bölümde, bu çalışmanın ekonometrik yöntemi olması nedeniyle yapısal kırılmalı birim kök testi ile yapısal kırılmalı Maki eşbütünleşme testi tanıtılarak çalışmanın teorik çerçevesi açıklanmıştır. Beşinci bölümde, uygulanan ekonometrik modeller sonucunda elde edilen bulgular özetlenmiş ve yorumları yapılmıştır. Çalışmanın son bölümü ise sonuçlar ve önerilere ayrılmıştır.

\section{TÜRKIYE EKONOMISINDE UYGULANAN EKONOMİ VE İHRACAT POLITIKALARI}

1923 y1lından itibaren Türkiye ekonomisinde çeşitli dönemlerde farklı ekonomi politikaları uygulanmıştır. $\mathrm{Bu}$ bölümde dönemlere göre uygulanan ekonomi politikaları incelenecek ve bu politikalar sonucunda gerçekleşen ihracat ve GSYİH verileri incelenecektir. Cumhuriyetin ilk kurulduğu yılların ekonomik gelişmelerini inceleyebilmek ve kendisinden önceki dönem ile süreklilik ve ayrılıklarını inceleyebilmek amacıyla Osmanlı ekonomisinin kısa bir özeti ile başlanacak ve ardından dönemler incelenecektir.

\subsection{Osmanlı İmparatorluğu'ndan Kalan Miras}

Osmanlı İmparatorluğu'nun 17 ve 18. yüzyıllarda Avrupa ile yaptığı dış ticaretin önemli artışlar gösterdiği, Avrupa mallarının Doğu Akdeniz pazarlarını istila etmesinin ise 19. yüzyılın ilk çeyreğinde, sanayi devriminden sonra başladığı bilinmektedir (Pamuk, 2000:139). Avrupa ülkelerinde başlayan merkantilizm döneminde hala Osmanlı ekonomisi, sağlam temelleri nedeniyle işleyen bir yapıya sahiptir. Ticari imtiyazlar her ne kadar 18. yüzyıldan sonra imparatorluğun zayıflamasına bağlı olarak Avrupalı devletler tarafindan gittikçe artan şekilde kötüye kullanılmış olsa da, bu yüzyıla kadar devlet ve ekonomi açısından herhangi bir tehdit veya zarar ifade etmemektedir (İnalc1k, 2000:247-250).

Merkantilizm süreci, Avrupa'da ortaya çıkan ve sanayi devrimine de öncülük eden homojen olmayan bir süreci ifade etmektedir. Avrupa ülkelerinin iktisadi gelişmesinde önemli bir yer tutan merkantilizm uygulamaları ve çeşitli ülkelerdeki bu doktrine bağlı iktisat politikaları birbirinden oldukça farklılık arz etmektedir. Bazı ülkelerde dış ticareti koruyacak ve ulusal ekonomi politikalarına öncelik veren bir iktisadi politika izlenirken, bazıları 
liberalizme zaman içinde açılmaya yönelen bir iktisat politikasını merkantilizm adına da olsa sürdürmüşlerdir (Kazgan, 1981:13). Merkantilizmin ilk amac1, devletin değerli maden biriktirmesi ve bu madenleri elinde tutmasıdır. Değerli madenler, güç ve refah göstergesi sayılmakta, savaş zamanlarında önemli bir kaynak olarak görülmektedir (Hafter, 1964:6). Değerli maden yataklarına sahip olmayan ülkelerin, bu madenlere ulaşmasının yolu olarak dış ticaretin arttırılması fikri merkantilistlerin temel felsefesini oluşturmaktadır. Ancak uluslararası ticaretin geliştirilmesiyle güç ve refahın sağlanabileceğine özellikle vurgu yapılmaktadır (Gomes, 1987:39). Avrupa merkantilizmin bir diğer amacı ise, ulusal sanayinin oluşturulması ve buna bağlı olarak ithal ikameci bir dış ticaret politikasının hayata geçirilmesidir. $\mathrm{Bu}$ nedenle merkantilist uygulamaları benimseyen devletler, ithal edilmekte olan malları kendi ülkelerinde üretebilmek için gerekli önlemleri almış, ulusal bir ekonomik yapı inşa etmeye çalışmışlardır (Hafter, 1964:7,8). İspanya'da merkantilizm, Peru ve Antillerden sağladığı altınlarla zenginleşmek olarak görülürken, İngiltere ve Fransa'da dış ticaret fazlası vermek suretiyle zenginleşmek olarak algılanmıştır (Kazgan, 1981: 17-22).

Osmanlı İmparatorluğu'nun merkantilizm ile ilk teması, Kanuni Sultan Süleyman döneminde Fransa ile imzalanan kapitülasyon anlaşması ile olmuştur. Kapitülasyonlar ile imparatorluğun zenginleşmesi hedeflenmiş olsa da, uzun vadede Osmanlı İmparatorluğu, batı devletleri için bir açık pazar haline gelecektir. Bu ilk karşılaşmadan sonra diğer Avrupa ülkeleri de Osmanlı imparatorluğu ile benzer anlaşmalar imzalayarak çeşitli imtiyazlar elde etmiş ve Osmanlı ekonomisi bir açık pazar haline getirilmiştir. Ayrıca siyaseten zaaflar da baş göstermeye başlamış ve ticaret, faizcilikle para kazanmaya başlayan çoğu yerli konsolosların resmi sıfatları, hükümetle ilişkilerinde onlara avantajlı bir durum sağlamıştır (Çadırcı, 1991:1$6)$.

Tüm bu olumsuzluklara rağmen, 18. yüzyılın başında Osmanlı ekonomisi hala Avrupa ile boy ölçüşecek durumdadır. Tablo 1, bu dönemdeki Osmanlı İmparatorluğu'nun ihraç ettiği malları göstermektedir. Tablodan görüldüğü gibi, Osmanlı ekonomisi, üretim ve ihracat yapacak güçte bir yapıya sahiptir. 
Tablo 1. Osmanlı İmparatorluğu'nun 18. yüzyıl başında ihraç ettiği mallar

\begin{tabular}{|c|c|}
\hline MALLAR & $\begin{array}{l}\text { MALLARIN ÜRETİM YERİ VEYA İHRAÇ } \\
\text { YERİ }\end{array}$ \\
\hline Pamuk ve yün & İzmir, Selanik, Lübnan \\
\hline Keçi kılı ve ipliği & İstanbul, İzmir \\
\hline Ham ipek & Trablusgarp, Kıbrıs, İzmir, Mora, Halep \\
\hline Zeytinyağ 1 & Girit \\
\hline Tiftik yünü & İzmir \\
\hline Hayvan derisi & Misır, İstanbul \\
\hline Safran ve keten & İzmir \\
\hline Buğday & Mora, Selanik \\
\hline Pirinç & Dimyat, Misır \\
\hline Moka kahvesi & Kahire \\
\hline Kuru üzüm & Mora \\
\hline Sinameki & Misir, Trablus \\
\hline Keten kumaşlar & Misir \\
\hline Pamuklu kumaş & Halep \\
\hline Halı ve aba & İzmir, Selanik \\
\hline Saten & Halep \\
\hline İpek mendil ve örtü & İstanbul, İzmir, Halep, Kıbrıs \\
\hline
\end{tabular}

Kaynak: Kazgan (1981: 37)

Bu noktada Osmanlı İmparatorluğu, Fransa ile 1740 yılında bir kapitülasyon anlaşması daha imzalamıştır. Bu anlaşmanın kendisinden öncekilerden farkı ise sürekli olmasıdır. I. Mahmut döneminde imzalanan bu anlaşma, gelecek dönemleri de kapsaması bakımından sürekli kapitülasyon olarak da anılmaktadır (Pamir, 2002: 89). Bu kapitülasyonlar sonun başlangıcı olmuştur. İngiltere ve Fransa, merkantilizm dönemi boyunca korumacı bir iktisat politikası izlemiş, gümrük vergileri ile yerli üretimini güvence altına almış ve bu yolla hem üretimini hem de ihracatını arttırabilmiştir. Oysa Osmanlı İmparatorluğu'na hep bunun tersini önermiş ve her seferinde de kabul ettirmişlerdir. Bu noktada, Osmanlı ekonomisinin yapısı ile batı devletlerinin ekonomik yapısının birbirinden farklı işleyişlerini de göz önüne almak 
gerekir. Merkantilizm dönemi, Osmanlı'nın ne feodal ne de kapitalist olan ekonomisinin batıda yeni yeni başlayan kapitalizm ile karşılaşmasının getirdiği ilk bunalımdır. Osmanlı düzeni, bu karşılaşmanın yarattığı bunalımı bir yıkılış aşamasına kadar vardıran yolda yürümeye 19. yüzyıla kadar şaşılacak bir direniş ile devam ettirecektir (Berkes,2013:265).

Avrupa'da merkantilizm süreci ile sağlanan sermaye birikimi, sanayi devriminin de temelini oluşturmuştur. Sanayi devrimi, ilk olarak İngiltere'de ortaya çıkmıştır. Üretim tekniklerinde yaşanan gelişmeler ve buluşlar da tıpkı sermaye birikimi gibi sanayi devrimini tetikleyen unsurlar olmuştur. Makineleşmenin İngiltere'de başlamasının nedenleri; artan talep, yeterli miktarda sermayenin varlığ 1 ve tarımda gerçekleşen devrimdir (Wallerstein, 2011: 16). Sanayi devriminin en önemli itici gücü olan teknik gelişme, aslında bu dönemde ortaya çıkan yeni bir insan tipi sayesinde gerçekleşmiştir. $\mathrm{Bu}$ insanlar, eğitimli ve eski tip üretim yapan tezgahları dönüştürmeye ve yeni buluşlar yapmaya başlamışlardır (Kazgan, 1981:67). Devrim niteliğinde gerçekleşen buluş ise buhar makinesinin icadı olmuştur (Türkcan, 2009:48). Buhar makinesinin icadı ve üretim tekniklerinde yaşanan diğer gelişmeler sayesinde seri üretime geçilmiş ve fabrika kavramı ortaya çıkmıştır.

Sanayi devrimi sürecinde Osmanlı imparatorluğu, Avrupa ile ekonomik olarak bütünleşmenin yollarını aramaktadır. Bu bütünleşmenin ilk adımı, 1838 yılında İngiltere ile imzalanan Baltalimanı Ticaret Anlaşması olmuştur. Bu anlaşma ile Osmanlı İmparatorluğu, dış ticaretteki tekelci düzenden, özel sınırlamalardan ve olağanüstü durumlarda getirilen ek vergi koyma hakkından vazgeçmiştir (Pamuk, 2009:29-30). Anlaşmanın doğal sonucu olarak Osmanlı, Avrupa ekonomilerinin açık pazarı haline gelmiş, dış ticaretin hem coğrafi yapısı hem ürün yapısı değişmiştir (Dura ve Altıparmak, 2000:23). Ayrıca, Osmanlı'nın bağımsız dış ticaret politikası izleme gücü ortadan kalkmış ve bu durum, fabrika kurma girişimleri başladığında gümrük tarifeleri arttırılamadığı için sanayileşme girişimlerinin yavaş ilerlemesine neden olmuştur (Pamuk, 2015:209). Tüm bu gelişmeler sonucunda, Osmanlı İmparatorluğu ekonomisi, hammadde ihraç eden, bitmiş mamuller ithal eden bir yapıya dönüşmüştür (Dura ve Altıparmak, 2000:23). 1838 yılında İngiltere ile imzalanan anlaşmadan sonra, 1851 y1lına kadar ilerleyen süreçte diğer Avrupa ülkeleri ile de benzer anlaşmalar yapılmıştır (Baskıcı, 2005:49).

1838 Ticaret Anlaşması'nın ardından 1839 yılında bir siyasal gelişme yaşanmış ve tanzimat fermanı ile yeni bir toplumsal anlayış başlamıştır. Tanzimat fermanı ile Osmanlı İmparatorluğu içinde yaşayan azınlıklara ve yabancılara hukuki ayrıcalıklar tanınmıştır. Azınlıklar, yeni haklarını kullanarak ticaret hayatındaki üstünlüklerini pekiştirmiş, bir yandan 
da bağımsızlık mücadelesine giren ana vatanlarına kaynak aktarmaya başlamışlardır (Kazgan,1981:71). Diğer yandan Tanzimat reformları ile memur sayısı artmış ve bütçe giderleri artmıştır. Yaşanan tüm bu gelişmeler sonucunda Osmanlı İmparatorluğu, mali açıdan büyük bir sıkıntıya düşmüş ve 1854 yılında dönemin padişahı Sultan Abdülmecid tarafindan 5.5 milyon Osmanlı lirası bir borçlanma anlaşması için hükümete yetki verilmişstir. Bunun üzerine hükümet 24 Ağustos 1854'te 3.3 milyon Osmanlı lirası tutarındaki ilk dış borç anlaşmasını imzalamıştır (Öner, 2005:338). Alınan bu borcu diğerleri takip etmiş ve Osmanlı ekonomisi, bir dış borç sarmalına girmiştir. Dış borçlar verimli kullanılmayıp tüketim ve israfa yönelmiştir (Sayar, 1977:191). 1875 yılına gelindiğinde Osmanlı, aldığ 1 dış borçların faizlerini dahi ödeyemeyecek durumdadır. 1876 Nisan ayında bütün dış borç taksitlerinin ödemesi durdurulmuş ve bu durum 1881 Muharrem kararnamesine kadar sürmüştür (Müderrisoğlu, 1995:249). Bu kararname ile borçlar yeni bir düzene bağlanmış ve alacaklı devletler Düyun-u Umumiye adında bir örgüt kurarak borçlara karşılık gösterilen devlet gelirlerini doğrudan toplamaya başlamışlardır (Gürsoy, 1984:17).

1908 yılına gelindiğinde İkinci Meşrutiyet ilan edilmiş ve bozulmuş ekonomik yapının düzeltilmesi için politikalar üretme çabasına girilmiştir. 1913 ve 1915 yıllarında yapılan sanayi sayımları, bugünkü Türkiye sınırları içinde kalan Batı Anadolu ve Marmara bölgelerinde, 1908 yılından önce kurulmuş sanayi tesislerinin, 20 un değirmeni, 2 makarna, 6 konserve, 1 bira fabrikası, 2 tütün mağazası, 1 buz, 3 tuğla, 3 kireç, 7 kutu, 2 yağ, 2 sabun, 2 porselen imalathanesi, 11 tabakhane, 7 marangoz ve doğrama atölyesi, 7 yün, 2 pamuklu iplik ve dokuma, 36 ham ipek, 1 ipekli dokuma ve 5 sair dokuma fabrikası, 35 matbaa, 8 sigara kağıdı, 5 madeni eşya 1 kimyasal ürün fabrikasından ibaret olduğunu göstermektedir (Boratav,2015:20-21). 1910 yılında, Osmanlı'nın ihracatının \% 90’1 hammadde ve gıda maddelerinden, ithalatının büyük çoğunluğu ise bitmiş mamul mallardan oluşmaktadır. 1913 yılında ise ihracatın milli gelire oranı \%14, ithalatın milli gelire oranı \% 19 düzeyindedir. Tarımsal üretimin \% 26'sı ihraç edilmektedir (Buluş ve Mercan, 2002:150).

\subsection{3-1929 Dönemi}

İttihat Terakki iktidarından sonra, milli mücadele döneminde ekonominin önemi de iyice anlaşılmıştır. Bu nedenle henüz cumhuriyet kurulmadan 17 Şubat 1923'te İzmir'de iktisat kongresi toplanmıştır. İzmir'de toplanan Türkiye İktisat Kongresi'nin toplanma amacı, savaştan yorgun çıkmış olan iktisadi faktörlerin ve birimlerin birbirlerini tanımalarını sağlamak, onların ihtiyaçlarını tespit etmek, iktisadi konular üzerine dikkatleri çekmek ve iktisat politikalarını da bu sonuçlara göre belirleme isteğidir (Gökçen, 1998: 3256). Alınan 
kararlara göre, yerli üretim özendirilecek, lüks ithalattan kaçınılacak, ekonomik gelişmeye katkısı olmak koşuluyla yabancı sermayeye izin verilecektir (Yavi, 2001:282-283). Ayrıca iç gümrükler kaldırılacak, koruyucu gümrük tarifeleri kabul edilecek, sanayicilere kredi vermek üzere bir sanayi bankası kurulacaktır (Parasız, 1998:3).

1923-1929 dönemi, Türkiye ekonomisinde liberal dönem olarak adlandırılmaktadır. Bunun en önemli sebebi, iktisadi olarak Türkiye'nin kendisine seçtiği yolun liberal ekonomik model ile daha yakın ilişki içinde olduğunun düşünülmesidir (Koraltürk ve Çetin, 2013:331). İzmir İktisat Kongresi'nde yerli girişimcilerin oluşturulma kararı da bu fikri destekleyici niteliktedir. Literatürde "milli burjuvazi" olarak nitelendirilen bu sınıf, merkezinde devletin yer aldığı bir ekonomik modelin eksik kaldığı, hantallaştığı yerlerde devreye giren ve devletin "ulusal çıkarlarını" gözetecek şekilde faaliyet yürüten bir yerli girişimciler topluluğudur (Sarıbay, 1986: 198). Nitekim İş Bankası da milli bir burjuvazi oluşturmak ve yerli girişimcileri desteklemek amaciyla kurulmuştur (Cem, 1989: 289-290).

Milli bir burjuvazi yaratmak suretiyle sanayileşme hedefinin dış ticaret ayağ yerli üretim sayesinde ihracatın da arttırılması şeklindedir. İzmir İktisat Kongresi'nde alınan kararlar, bu dönemde korumacı ve ithal ikameci politikaların hedeflendiğini göstermektedir (Şahin, 2006:34). Ancak hedeflenen dış ticaret politikası, Lozan Anlaşması ve ek olarak imzalanan ticaret sözleşmesi nedeniyle uygulama alanı bulamamıştır. Bu sözleşmeye göre, gümrük tarifeleri beş yıl süreyle aynı kalacak, bazı istisnalar dışında ithalat ve ihracat yasakları kaldırılacak, yeni yasaklar da yürürlüğe girmeyecektir (Boratav, 2014:32). Böylece dış ticaret politikasındaki temel araçlardan biri olan gümrük tarifelerini değiştirme gücü Türkiye'nin elinden alınmıştır (Taşkın, 2003:135). Ayrıca incelenen dönemde, 1929 ekonomik krizi yaşanmıştır. Ekonomik krizin Türkiye'ye etkisi en fazla dış ticaret alanında yaşanmıştır. 1929 yılında 1928'e göre aslında miktar olarak daha fazla ihracat yapmış, ancak fiyatlar düştüğü için daha az döviz elde etmiştir. Bunun yanında, yabancıların elindeki şirketlerin devletleştirilmesi ve yeni demiryolları inşaatı da devlet bütçesine böyle bir dönemde fazladan yük bindirmiştir (Mango, 2007:538). 1923-1929 dönemine ait ihracat ve GSYİH göstergeleri Tablo 2'de verilmiştir. 
Tablo 2. 1923-1929 arasında ihracat ve GSYİH verileri (Bin ABD Doları)

\begin{tabular}{|l|l|l|}
\hline YILLAR & İHRACAT & GSYİH \\
\hline $\mathbf{1 9 2 3}$ & 50.790 & 1.129 .659 \\
\hline $\mathbf{1 9 2 4}$ & 82.435 & 1.427 .376 \\
\hline $\mathbf{1 9 2 5}$ & 102.700 & 1.809 .303 \\
\hline $\mathbf{1 9 2 6}$ & 96.437 & 1.957 .566 \\
\hline $\mathbf{1 9 2 7}$ & 80.749 & 1.745 .367 \\
\hline $\mathbf{1 9 2 8}$ & 88.278 & 1.641 .160 \\
\hline $\mathbf{1 9 2 9}$ & 74.827 & 2.084 .579 \\
\hline
\end{tabular}

Kaynak: TÜİK ve SBB

Tablo 2'deki veriler incelendiğinde 1924 ve 1925 yıllarındaki ihracat ve GSYİH değişimleri paralel seyretmektedir. Ancak 1924 yılında, ihracattaki artış, GSYİH artışının yaklaşık 2.5 katıdır. 1926 yılında ihracat azaldığı halde GSYİH artmıştır. Teşvik-i Sanayi Kanunu'nun çıkarıldığı 1927 yılında ise hem ihracat hem de GSYİH düşmüştür. 1928 yılında GSYH azalırken ihracat artmış, ekonomik krizin yaşandığı 1929 yılında ihracatta düşüş gözlemlenirken, GSYİH artışında incelenen dönemdeki rekor büyüme gerçekleşmiştir. $\mathrm{Bu}$ durum, Türkiye'nin 1929 krizinden düşen ihracat gelirleri şeklinde etkilendiğini göstermektedir.

\subsection{0-1939 Dönemi}

1929 ekonomik krizi sonrasında, Türkiye de diğer ülkeler gibi yeni iktisadi politika arayışlarına girmiştir. Liberal iktisat politikalarının dünyayı getirdiği kriz sonrasında liberalizm, hem dünyada hem de Türkiye'de etkisini yitirmiştir (Develi ve Özdoğan, 2020:11). Sovyetler Birliği’nin 1928 yılında uygulamaya koyduğu sanayileşme programının başarılı olmasından da etkilenen Türkiye, devletçi bir ekonomi modelini uygulamaya koymuştur (Coşar, 1995:11). Bu bağlamda 1934-1939 yıllarını kapsayacak şekilde Birinci Beş Yıllık Sanayi Planı hazırlanmış ve uygulamaya konulmuştur. Sanayi planının hazırlanmasına yol açan bazı gerekçeler; ülkede bir iktisadi birlik oluşturmak, düşük fiyatlarla hammadde ihraç eden bir ülke olmaktan kurtulmak, dış ticaret dengesini kurmak, bu sayede milli paranın değerini korumak, Türkiye'yi kendine lazım olan mamul maddeleri üreten bir sanayi memleketi haline getirmek olarak ifade edilebilir (Kutay, 1939:50).

Birinci Beş Yıllık Sanayi Planı ile ortaya konulan sanayileşme hedefi ile sanayi, 5 ana kolda değerlendirilmiştir. Bunlar; dokuma, maden, kağıt, kimya ve taş toprak sektörleridir 
(Sevgi, 1994:51). Devletçi sanayileşme, yatırım malları üretimini hedef alan bir sanayileşme değil, tüketim ve ara malı üretimine yönelik ithal ikameci bir sanayileşme modeli olarak düşünülmüştür (Parasız, 1998:50). Sanayileşmenin finansmanı, Sümerbank ve İş Bankası tarafindan karşılanmıştır. Finansmanın temel kaynağını ise tüketim malları üzerine konulan vergiler oluşturmuştur (Parasız, 1998:50). Birinci Beş Yıllık Sanayi Planı'nın süresi dolmadan 1936 yılında İkinci Beş Yıllık Sanayi Planı yapılmaya başlanmıştır. İkinci planda, ilk plandan farklı olarak ara malları ve yatırım malları üretimine ağırlık verilmiştir. Fakat İkinci Dünya Savaşı nedeniyle bu plan uygulanamamıştır (Kepenek ve Yentürk, 2001:68).

Tablo 3'de, incelenen döneme ait ihracat ve GSYİH göstergeleri verilmiştir.

Tablo 3. 1930-1939 arasında ihracat ve GSYİH verileri (Bin ABD Doları)

\begin{tabular}{|l|l|l|}
\hline YILLAR & İHRACAT & GSYİH \\
\hline $\mathbf{1 9 3 0}$ & 71.380 & 1.589 .075 \\
\hline $\mathbf{1 9 3 1}$ & 60.226 & 1.399 .740 \\
\hline $\mathbf{1 9 3 2}$ & 47.972 & 1.178 .030 \\
\hline $\mathbf{1 9 3 3}$ & 58.065 & 1.370 .723 \\
\hline $\mathbf{1 9 3 4}$ & 73.007 & 1.459 .680 \\
\hline $\mathbf{1 9 3 5}$ & 76.232 & 1.573 .124 \\
\hline $\mathbf{1 9 3 6}$ & 93.670 & 2.034 .356 \\
\hline $\mathbf{1 9 3 7}$ & 109.225 & 2.169 .289 \\
\hline $\mathbf{1 9 3 8}$ & 115.019 & 2.979 .553 \\
\hline $\mathbf{1 9 3 9}$ & 99.647 & 3.143 .855 \\
\hline
\end{tabular}

Kaynak: TÜiK ve SBB

Tablo 3'den görüldüğü gibi, incelenen dönemin ilk 3 y1lında hem ihracat hem GSYİH azalmaktadır. 1933'ten itibaren her iki değişkende de paralel bir artış gözlemlenmektedir. 1939 yılı ise ihracatın düşerken dolar bazında GSYİH'nin arttığ bir y1l olmuştur. Bu dönemin genelinde ihracat ile GSYİH verilerinin aynı yönde değiştiği görülmektedir.

\subsection{0-1949 Dönemi}

1939 yılında İkinci Dünya Savaşı'nın başlaması nedeniyle ikinci sanayi planı uygulanamamıştır. Savaş yıllarında Türkiye ekonomisi; içine kapanık, kendine yetmeye çalışan, dış ekonomik ilişkileri sınırlı bir hal almıştır (Parasız, 1998:59). Türkiye, her ne kadar savaşa katılmasa da süreç içerisinde 2 milyon kişi orduya alınmış ve bütçenin \% 60 ’`1 askeri 
harcamalara ayrılmıştır (Güner, 1978:45). 1941 yılı bütçe verilerine göre, 309.740.396 TL olan giderler kalaminin 77.095.000 TL'lik kısmı savaşa tedbir amaçlı ayrılmıştır (Duru, 2008:172). 1939 yılında 2.404 TL olan kişi başına gelir, 1945 yılında 1.259 TL düzeyine gerilemiştir (Yeşilyurt, 2016:296).

Yaşanan tüm bu olumsuzluklara karşı savaş döneminde iki kanun çıkarılmıştır. Bu kanunlardan ilki Milli Korunma Kanunu'dur. Bu dönemde uygulanan müdahaleci iktisadi ve mali kuralların temel dayanak noktası bu kanun olmuştur (Koçak, 1986:170). Milli Korunma Kanunu vasıtasıyla ekmek fiyatlarına üst sınır getirilmesi, ekmeğin tek tip olarak çıkarılması, fazla tüketimi engellemek adına ekmeklerin bayat olarak satılması, undan ekmek ve makarna dışında bir şey yapılmasının yasaklanması, hemen hemen tüm vergilerde artışların yapılması gibi sıkı tedbirler alınabilmiştir (Duru, 2008:162). Savaş döneminde çıkarılan ikinci kanun ise yüksek kazanç elde edenlerin vergilendirilmesi için uygulamaya konulan Toprak Mahsulleri Vergisi ve Varlık Vergisi'dir (Koçak, 1986:170).

Türkiye, dış ticaretini savaş yıllarında, dünyanın diğer ülkelerinde olduğu gibi, güçlükle yürütmüştür. İlgili yıllarda dış ticaret dengesi ortalama olarak hep fazla vermiştir. Savaşa girmeyen Türkiye, savaşan ülkelerin ihtiyaç duyduğu ürünleri sağladığı için ihracatta bir artış yaşamış, fakat ithal edilecek malları üreten ülkelerin kendi ihtiyaçlarını ancak karşılaması sonrasında ise ithalatta ciddi bir daralmayla karşılaşmıştır. Fakat ihraç mallarının fiyatlarına nazaran ithal mallarının fiyatları daha fazla arttığ için, artan ihracattan beklenen yüksek kârlar elde edilememiştir (Dokuyan, 2014:27). 1940 ile 1949 yılları arasındaki ihracat ve büyüme verileri Tablo 4'de özetlenmiştir.

Tablo 4. 1940-1949 arasında ihracat ve GSYİH verileri (Bin ABD Dolari)

\begin{tabular}{|l|l|l|}
\hline YILLAR & İHRACAT & GSYİH \\
\hline $\mathbf{1 9 4 0}$ & 80.904 & 3.662 .218 \\
\hline $\mathbf{1 9 4 1}$ & 91.056 & 4.559 .679 \\
\hline $\mathbf{1 9 4 2}$ & 126.115 & 9.440 .869 \\
\hline $\mathbf{1 9 4 3}$ & 196.734 & 14.066 .211 \\
\hline $\mathbf{1 9 4 4}$ & 177.952 & 10.185 .037 \\
\hline $\mathbf{1 9 4 5}$ & 168.264 & 8.333 .739 \\
\hline $\mathbf{1 9 4 6}$ & 214.580 & 7.264 .498 \\
\hline $\mathbf{1 9 4 7}$ & 223.301 & 5.335 .816 \\
\hline $\mathbf{1 9 4 8}$ & 196.799 & 6.745 .365 \\
\hline $\mathbf{1 9 4 9}$ & 247.825 & 6.433 .429 \\
\hline
\end{tabular}

Kaynak: TÜİK ve SBB 
Tablo 4’ten görüldüğü gibi; 1940, 1946, 1947, 1948 ve 1949 yıllarında ihracat ve GSYH, birbirinin tersi yönünde bir gelişim izlemektedir. 1942 yılında GSYH artışı, ihracattaki artışın yaklaşık 3 katıdır. 1944 ve 1945 yıllarında ise GSYH düşüşü, ihracattaki

düşüşün yaklaşık 3 katıdır. Özetle, incelenen dönemde ihracat ve GSYH verileri birlikte hareket etmiyor gibi görünmektedir.

\subsection{0-1959 Dönemi}

1950 yılından sonra uygulanan iktisat politikaları; devletçi karma ekonomi modelinden, ekonomide liberalizm ve serbest piyasa hakimiyetinin kurulmasına geçiş, kamu iktisadi teşebbüslerinin özelleştirilme isteği ve özel sektörün desteklenmesi şeklindedir (Kılıçbay, 1997:16). 1946 yılından itibaren ithalattaki miktar ve fiyat kısıtlamalarının kaldırılmış olmasıyla birlikte liberalizm anlayışının egemenliği birleşince ithalatta bir artış yaşanmıştır. Bunun en önemli nedeni, özellikle 1950 yılından itibaren gelen yabancı sermaye ve dış yardımların yeni bir tüketim talebi oluşturmasıdır. Diğer bir neden ise, izlenen ekonomik gelişme politikasının ithal girdi kullanımına dayanmasıdır (Kepenek ve Yentürk, 2001:120).

1950 yılından itibaren liberal ekonomi modelinin benimsenmiş olmasına rağmen kamu müdahalesinde bir azalma olmamış, devletin ekonomi içindeki payı azaltılamamış, üstelik var olan kamu iktisadi teşebbüslerine yenileri eklenmiştir (Takım, 2012:166). İncelenen dönemde; uygun iklim koşulları ve devam eden Kore savaşı nedeniyle tarımsal ürünlere yönelik talebin artması, tarımsal üretimi arttırarak ekonomik gelişmeyi hızlandırmıştır (Takım, 2012: 167). Ancak 1950’li yıllar, kendisinden önceki ve sonraki dönemlere göre, milli gelir büyüme hızının belirgin bir biçimde düşük olduğu bir dönem olmuştur. Milli hasılanın ortalama yıllık büyüme oranları \% 4.4 olarak gerçekleşmiştir (Boratav, 2015:113). Sanayi kesimi ise göreli bir durağanlığa girmiş, ancak yine de tarıma göre daha hızlı büyüyebilmiştir. 1954-1961 arasında sanayinin ortalama büyüme hızı \% 4.3 olarak gerçekleşmiş, böylece milli hasıla içinde sanayinin payı 1952 yılında \% 14'ün altındayken dönem sonunda \% 18 düzeyine yaklaşmıştır (Boratav, 2015:115).

Dış ticarette ise incelenen dönemde, liberal bir diş ticaret rejimi içinde diş dengenin bozulduğu düşünülerek dış ticaret kontrollerine gidilmiştir. Bu çerçevede 1954 yılında yeni bir dış ticaret rejimine geçilerek 4/3321 sayılı kararname ile yeni kontrol ve sinırlamalar getirilmiştir. Dış ticarette kontrollere ve korumacılığa yol açan temel etken, serbest ticaret rejiminin sürekli ve giderek büyüyen dış açıklara yol açmasıdır (Boratav, 2015:112). Ancak 
alınan önlemler, ithalatın yapısının bozulmasına yol açmış, 1948 yılında yapılan ithalatın \% 28'i makine ve araçlar, \% 36'sı hammaddeler, \% 25'i tüketim malları, \% 11'i inşaat malzemelerinden oluşurken 1962 yılında tüketim malları ithalatının toplam ithalat içindeki payı \% 7'ye, inşaat malzemelerinin payı \% 5'e gerilemiştir (Kepenek ve Yentürk, 2001:120). Dış ticaret rejiminde uygulanan kontroller sonucunda ithalatta yaşanan daralma nedeniyle, ithalata büyük ölçüde bağımlı olan sanayi sektörlerinde de küçülmeye yol açmıştır (Balkanlı, 2002:300). Yaşanan bu olumsuz gelişmeler ve diş baskılar nedeniyle 4 Ağustos 1958'de doların TL karşısında 2.2 misli değerlenmesi sonucunu doğuran bir devalüasyon yapılmıştır. Ayrıca 4 Ağustos kararlarıyla; dış ticaret kontrollerinin gevşetilmesi, Milli Korunma Kanunu uygulamalarının durdurulması, kamu işletmesi ürünlerine zamlar yapılması ve bütçe açıklarının daraltılması gibi tedbirler alınmıştır (Boratav, 2013:113). İncelenen dönemde ihracatın gelişimi ve GSYİH verileri ise Tablo 5’te özetlenmiştir.

Tablo 5. 1950-1959 arasında ihracat ve GSYİH verileri (Bin ABD Doları)

\begin{tabular}{|l|l|l|}
\hline YILLAR & İHRACAT & GSYİH \\
\hline $\mathbf{1 9 5 0}$ & 263.424 & 6.888 .685 \\
\hline $\mathbf{1 9 5 1}$ & 314.082 & 8.273 .927 \\
\hline $\mathbf{1 9 5 2}$ & 362.914 & 9.513 .999 \\
\hline $\mathbf{1 9 5 3}$ & 396.061 & 11.090 .168 \\
\hline $\mathbf{1 9 5 4}$ & 334.924 & 11.308 .382 \\
\hline $\mathbf{1 9 5 5}$ & 313.346 & 13.584 .170 \\
\hline $\mathbf{1 9 5 6}$ & 304.990 & 15.665 .762 \\
\hline $\mathbf{1 9 5 7}$ & 345.217 & 20.826 .361 \\
\hline $\mathbf{1 9 5 8}$ & 247.271 & 24.869 .743 \\
\hline $\mathbf{1 9 5 9}$ & 353.799 & 31.030 .174 \\
\hline
\end{tabular}

\section{Kaynak: TÜiK ve SBB}

Tablo 5'ten görüldüğü gibi, incelenen dönemin ilk dört y1lında ihracat ve GSYİH artışları uyumlu gözükmektedir. Ancak 1954 yılında dış ticaret rejiminde uygulanan değişikliklerin ardından bu uyum ortadan kalkmaktadır. Ekonomi büyümeye devam ederken ihracatta daralma yaşanmaktadır. İhracatta en fazla küçülmenin yaşandığ 1 yıl, ekonomik krizin yaşandığ 1958 yılı olmuştur. 1958 yılında yapılan devalüasyon ve dış ticaret rejiminin serbestleştirilmesiyle birlikte 1959 yılında ihracatın tekrar yükselişe geçtiği görülmektedir. 


\subsection{0-1979 Dönemi}

1960-1979 döneminin başında kurulan Devlet Planlama Teşkilatı, esasen dönemin ekonomik politikalarının da habercisi olmuştur. DPT'nin kurulmasıyla 1950'li yılların liberal ekonomi anlayışı, yerini planlı ekonomi anlayışına bırakmıştır (Memiş, 2020: 274). Ancak hazırlanan planlar; katı bir ekonomik modeli göstermemekte, kamu sektörü için zorunlu hedefler, özel sektör için yol gösterici hedefler koymaktadır (Kazgan, 1999:78). Bu dönemdeki planlı ekonomi anlayışını 1930'lu yılların devletçi ekonomisinden ayırmak gerekir. 1930'lu yıllarda bilinçli olarak başlatılan yaygın tüketim mallarında ithal ikameci sanayileşme modeli, 1960’lı yılların sosyopolitik yapısı ve bölüşüm ilişkileri tarafından biçimlendirilmiştir (Boratav, 2015:120). Bir başka deyişle, gelişen burjuvazi sınıfının artan tüketim malları talebinin karşılanması gereği doğmuş ve bu durum, günün koşullarında ithal ikameci sanayileşmeyi zorlamıştır. Ancak, sanayileşmenin zayıf olması nedeniyle üretim artarken ithal girdi talebi de artmış ve böylece ithal ikameci sanayileşme modelinin ithalat bağımlılığ1 düşürülememiştir.

İthal ikameci sanayileşme modelinin ithalat bağımlılı̆̆ını arttırması, ihracat artışı ile dengelenmeye çalışılmış, ancak bu noktada da hedeflenen düzeylere ulaşılamamıştır. Tüm bunlara rağmen bu dönemde yüksek bir büyüme temposu sürdürülebilmiştir. Bunun en önemli nedeni, ekonomiye büyük oranda dış kaynak enjekte edilmesi olmuştur. Bir diğer neden ise bu dönemde ülke ekonomisine gelen işçi dövizleri olmuştur (Boratav, 2015:124). Planlı dönemin ilk yarısında iç pazara yönelik üretim teşvik edilirken, 1970 yılında yeni bir devalüasyon yapılarak, ihracat teşvik edilmeye çalışılmışsa da, dünya ticaret hacminin de artması nedeniyle, Türkiye'nin ihracatının dünya ihracatı içindeki payı değişmemiştir (Özcan, 1998:44).

1970-1975 arasında, TL’nin değeri düşürülmemiştir. Ayrıca bu dönemdeki işçi dövizleri ve dış kredilerin artışı nedeniyle bir rahatlama yaşanmıştır. Ancak 1973 yılında petrol fiyatlarının aşırı yükselmesi sonucunda Türkiye ekonomisi, yeni bir krize doğru sürüklenmeye başlamıştır. 1976 yılına gelindiğinde ihracatın ithalatı karşılama oranı 1/3 seviyesine kadar gerilemiştir (Boratav, 2015:131). Dönem sonunda 1980 yılı verilerine göre, 10.8 milyar dolarlık dış ticaret hacminin 7.9 milyar dolarlık kısmı ithalat olarak gerçekleşmiştir. Özellikle ithalat bağımlılığının yüksek olduğu petrol fiyatlarındaki ve kimya sektörünün ithal girdi fiyatlarındaki yükselişler nedeniyle bu durum ortaya çıkmıştır. Ayrıca dünyadaki eğilim; ekonominin serbest piyasa modeline göre düzenlenmesi, mal ve hizmet 
piyasaları, döviz piyasaları ve faiz piyasalarının serbest bırakılması ve fiyatların piyasa koşullarında devlet müdahalesi olmadan belirlenmesi noktasına gelmiştir. Bu eğilimlerin başını ise ABD ve İngiltere çekmektedir (Aydın, 2019:13). Dolayısıyla Türkiye'nin de dünyadaki genel eğilime uyarak planlı ekonomi anlayışına son vermesinin şartları 1980 yılı itibariyle oluşmuştur. 1960-1979 yılları arasındaki ihracat ve GSYİH verileri Tablo 6'da özetlenmiştir.

Tablo 6. 1960-1979 arasında ihracat ve GSYİH verileri (Bin ABD Doları)

\begin{tabular}{|c|c|c|}
\hline YILLAR & İHRACAT & GSYİH \\
\hline 1960 & 320.731 & 19.628 .386 \\
\hline 1961 & 346.740 & 10.902 .116 \\
\hline 1962 & 381.197 & 12.675 .345 \\
\hline 1963 & 368.087 & 14.701 .960 \\
\hline 1964 & 410.771 & 15.625 .867 \\
\hline 1965 & 463.738 & 16.811 .942 \\
\hline 1966 & 490.508 & 20.031 .481 \\
\hline 1967 & 522.334 & 22.235 .941 \\
\hline 1968 & 496.419 & 24.779 .405 \\
\hline 1969 & 536.834 & 27.690 .722 \\
\hline 1970 & 588.476 & 25.915 .847 \\
\hline 1971 & 676.602 & 23.181 .809 \\
\hline 1972 & 884.969 & 29.341 .375 \\
\hline 1973 & 1.317 .083 & 36.949 .966 \\
\hline 1974 & 1.532 .182 & 50.943 .657 \\
\hline 1975 & 1.401 .075 & 63.724 .659 \\
\hline 1976 & 1.960 .214 & 72.938 .008 \\
\hline 1977 & 1.753 .026 & 83.428 .722 \\
\hline 1978 & 2.288 .163 & 91.217 .379 \\
\hline 1979 & 2.261 .195 & 111.456 .960 \\
\hline
\end{tabular}

Kaynak: TÜIK ve SBB

Tablo 6'daki verilerden dönem boyunca GSYİH'nin düzenli bir artış içinde olduğu görülmektedir. Sadece 1960, 1970 ve 1971 yıllarında dolar bazında bir küçülme söz konusudur. Aynı dönemde ihracat ise 5 defa daralmıştır. Fakat dönem başı ve dönem sonu karşılaştırıldığında ihracat 7 katına çıkarken, GSYİH yaklaşık 5.5 katına çıkmıştır. 


\subsection{0-2001 Dönemi}

1973 petrol krizinin ardından dünyada başlayan liberalleşme ve küreselleşme süreçleri, 1980’li yıllarda hız kazanmıştır. Küreselleşme eğilimi, ulusal ekonomilerin dünya piyasalarıyla eklemlenmesine ve bütün iktisadi karar süreçlerinin dünya kapitalizminin sermaye birikimine yönelik olarak belirlenmesine yol açmıştır (Yeldan, 2001:13). 1980 yılına ekonomik kriz koşullarında giren Türkiye, dünyadaki bu eğilime 24 Ocak kararları ile eklemlenmiştir. 24 Ocak kararlarının temeli, devletin ekonomiye olan müdahalesinin en aza indirilmesi şeklindedir. Alınan diğer kararlar ise; mal ve hizmet fiyatlarının, döviz kurunun serbest piyasada oluşması, faiz oranlarının yükseltilmesi, reel ücretlerin düşürülmesi gibi liberal önlemleri içermektedir (Çavdar, 2004:258). 24 Ocak kararlarının diğer bir uygulama alanı ise dışa açılma ve ihracata dayalı büyüme modeli olmuştur.

Uygulamada 24 Ocak kararlarının en başarılı olduğu alan ihracatın arttırılması olmuştur. İhracat, Tablo 6'dan görüldüğü gibi 10 y1llık süreçte yaklaşık 4 katına çıkmıştır. Ancak faizlerin serbest bırakılması sonucunda ortaya çıkan banker krizi, enflasyonun düşürülememesi, dış borç yükünün giderek yükselmesi gibi unsurlar 24 Ocak kararlarının uygulamada yetersiz kaldığı alanlar olmuştur. Finansal krizlerin de temellerini barındıran liberalleşme süreci, 8 yıllık süre sonunda Türkiye ekonomisini bir ekonomik krizle karşı karşıya bırakmıştır (Kazgan, 1999:165).

24 Ocak kararlarıyla mal hareketlerinin serbestleşmesine 1989 yılı Ağustos ayında konvertibilitenin de yürürlüğe girmesi eklenmiştir. Böylece sermaye hareketlerinin serbestleşme süreci de başlamıştır. 32 sayılı kararname ile Türkiye, sermaye hareketleri bakımından tamamen serbest olmuştur. Sermaye hareketlerinin tümüyle serbestleştirilmesinin iki farklı sonucu olmuştur. Bunlardan biri Merkez Bankası'nın döviz yükümlülüklerinde hızlı bir artış olması, diğeri de dolarizasyon, yani ABD dolarının ekonomide yaygın olarak kullanılmaya başlamasıdır (Kepenek ve Yentürk, 2001:254).

Sermaye hareketlerinin de serbestleştirilmesiyle birlikte Türkiye ekonomisi finansal krizlerle iç içe yaşamaya başlamıştır. İncelenen dönemin en önemli iktisadi olayı, 1994 yılında yaşanan ekonomik kriz olmuştur. Kazgan (2017), kriz aylarındaki net sermaye çıkışını 4.2 milyar olarak ifade etmektedir. 1994 krizinin en önemli nedeni, kamu açıklarının finanse edilme biçimi politikasındaki yanlış uygulamalardır. Hükümetin faizleri düşürme çabasına girmesi ve Merkez Bankası avanslarına yüklenilmesi, finansal krize sebep olmuştur (Özatay, 2009:75). Faizleri düşürme çabasının bir etkisi de, sermaye çıkışlarına neden olmasıdır. 
Yüksek faiz ve ucuz kur avantajından faydalanmak için gelen yabancı sermaye, 1989 yılından sonra ekonomide bir genişleme meydana getirmiştir. Artan sıcak para girişinin yarattığ 1 genişleme, hem iç talebi canlı tutmuş hem de ithalatı finanse etmiştir. Böylece her ne kadar enflasyon yüksek olsa da ekonomi büyümüştür. Ancak orantısız bir nicelikte gelen bu sicak para, ülkeyi terk ettiğinde ekonomik daralmaya ve 1994 krizine sebep olmuştur (Aydın, 2019:27).

1994 krizinden çıkış için 5 Nisan 1994 tarihinde bir dizi önlemler alınmıştır. 5 Nisan kararlarının genel amaçları; enflasyonun hızlı bir biçimde düşürülmesi, ihracatın arttırılıp ithalatın azaltılması, dış borçların sınırlandırılması, kamu gelirlerinin arttırılıp, kamu harcamalarının azaltılması, sosyal güvenlik ve özelleştirme alanlarında reformlar yapılması şeklindedir (Altınoğlu ve Güloğlu, 2002:18). Alınan önlemler sonucunda hedefler tam olarak gerçekleştirilememiştir. Özellikle enflasyonun düşürülmesinde başarı sağlanamamıştır. Politik istikrarsızlık ve popülist uygulamalar nedeniyle alınan tedbirler de tam olarak uygulanamamıştır. Ancak tüm bu olumsuzluklara rağmen Türkiye ekonomisi, 1994 yılının son çeyreğinde, ihracatın verdiği ivmeyle toparlanma sürecine girmiştir (Kazgan, 1999:314). Dönemin ihracat ve GSYİH verileri Tablo 7'de özetlenmiştir. 
Tablo 7. 1980-2001 arasında ihracat ve GSYİH verileri (Bin ABD Dolari)

\begin{tabular}{|c|c|c|}
\hline YILLAR & İHRACAT & GSYİH \\
\hline 1980 & 2.910 .122 & 92.861 .166 \\
\hline 1981 & 4.702 .934 & 96.919 .591 \\
\hline 1982 & 5.745 .973 & 87.408 .135 \\
\hline 1983 & 5.727 .834 & 83.086 .692 \\
\hline 1984 & 7.133 .604 & 80.721 .998 \\
\hline 1985 & 7.958 .010 & 91.411 .693 \\
\hline 1986 & 7.456 .726 & 103.301 .102 \\
\hline 1987 & 10.190 .049 & 117.867 .127 \\
\hline 1988 & 11.662 .024 & 124.595 .842 \\
\hline 1989 & 11.624 .692 & 146.068 .596 \\
\hline 1990 & 12.959 .288 & 205.381 .935 \\
\hline 1991 & 13.593 .462 & 205.327 .768 \\
\hline 1992 & 14.714 .629 & 215.652 .462 \\
\hline 1993 & 15.345 .067 & 244.115 .064 \\
\hline 1994 & 18.105 .872 & 181.214 .714 \\
\hline 1995 & 21.637 .041 & 231.738 .921 \\
\hline 1996 & 23.224 .465 & 249.270 .316 \\
\hline 1997 & 26.261 .072 & 259.812 .287 \\
\hline 1998 & 26.973 .952 & 277.427 .867 \\
\hline 1999 & 26.587 .225 & 253.382 .484 \\
\hline 2000 & 27.774 .906 & 271.546 .016 \\
\hline 2001 & 31.334 .216 & 200.650 .918 \\
\hline
\end{tabular}

Kaynak: TÜIK ve SBB

İhracata dayalı büyüme modelinin benimsendiği 1980 sonrası dönemde ihracatın sürekli bir artış içinde olduğu görülmektedir. 1980 yılında yaklaşık 3 milyar dolar olan ihracat, aradan geçen 20 yılda 10 katına çıkmıştır. GSYİH de 1994 ve 2001 kriz yılları dışında genelde artış eğilimindedir. İhracat ise kriz yıllarında dahi artış göstermiştir. Ancak GSYİH artışının, ihracattaki artışın gerisinde kaldığı görülmektedir. İncelenen dönemde genel olarak ihracat ve GSYİH aynı yönde hareket etmektedir.

\subsection{2-2021 Dönemi}

Türkiye ekonomisi, 2001 yılında tekrar bir finansal kriz ile sarsılmıştır. Kriz öncesinde rekabet şartlarına ayak uyduramayan bankalar, iyi şekilde de yönetilemeyince ciddi sorunlarla karşılaşmışlardır. Özellikle bankaların açık pozisyonları, finansal kırılganlığı arttırmıştır. Ayrıca bankaların borçlarının vadesi kısa, alacaklarının vadesi ise uzun durumdadır. Bu nedenlerle kriz öncesinde bankacılık sektörü, hem faiz artışlarına hem de kur artışlarına karşı 
son derece kırılgan durumdadır (Özatay, 2009:86). Bankacılık sektörünün diğer bir sorununun ise geri dönmeyen krediler olduğu görülmektedir. Geri dönmeyen kredi oranı, 1997 yılında \% 2.4 iken 2000 y1lında \% 11.6 düzeyindedir (Özatay, 2009:86). Kamu bankaları ise benzer bir sorunu görev zararları şeklinde yaşamıştır. Devlet tarafından kamu bankalarına verilen özellikle tarım sektörünü düşük faizle destekleme görevi nedeniyle oluşan kamu alacakları görev zararı olarak yazılmıştır (Aydın, 2019:46).

2001 krizini aşabilmek adına kamuoyuna Güçlü Ekonomiye Geçiş Programı adıyla açıklanan bir dizi önlemler alınmıştır. 14 Nisan ve 15 Mayıs 2001 tarihlerinde iki aşamalı olarak açıklanan programın hedefleri; TL'nin dalgalanmaya bırakılmasıyla enflasyon oranının önce artması, ancak yılın ikinci yarısında düşmesi, faiz dış1 denge/GSMH oranının \% 6.5 düzeyine çekilmesi, bankacılık sisteminin yeniden düzenlenmesi şeklindedir (Taşar, 2010:82). Dış ticaret alanında ise programın öngörüsü; ekonomideki daralma ve iç talepteki düşüş nedeniyle ithalatın azalması, verimlilik artışı sayesinde ihracatın artması biçimindedir. Güçlü Ekonomiye Geçiş Programının temel kur politikası ise dalgalı kur politikası olarak açıklanmıştır.

Güçlü Ekonomiye Geçiş Programının uygulamaya konulmasıyla ekonomide başlayan iyileşme, 2008 yılına kadar devam etmiştir. 2002 yılında \% 29.8 olan enflasyon oranı, 2004 y1lında \% 9.3'e, 2007 yılında ise \% 8.4 düzeyine gerilemiştir (Özsoylu, 2016:262). 2007 yılında ABD'de başlayan ekonomik kriz, kısa bir zaman içinde küresel bir krize dönüşerek birçok ülkeyi etkilemiştir. 2008 yılının ikinci yarısından itibaren Türkiye'yi etkisi altına alan küresel krizin sonucunda Türkiye ekonomisi, 2009 yılında \% 4.7 oranında küçülme yaşamıştır. Krizin en ağır seyrettiği üç aylık dönem Ocak, Şubat, Mart 2009 ayları olmuştur. Bu dönemde milli gelir bir yıl öncesine göre \% 14.6 oranında düşmüştür (Boratav, 2015:213).

Türkiye ekonomisinin krizden çıkış süreci de çok hızlı olmuştur. 2009 yılının Kasım ayından sonra Türkiye'ye dış kaynak girişleri hızla artmış, ekonomi toparlanmaya başlamıştır. $\mathrm{Bu}$ toparlanma süreci sonunda; 2010 yılında işsizlik \% 11.9'a, enflasyon oranı \% 6.4 seviyesine gerilemiştir. Ekonomik büyüme ise \% 8.5 seviyesinde gerçekleşmiştir. Türkiye ekonomisindeki olumlu gidişat, 2015 yılına kadar devam etmiştir. 2015 yılında dolar kurunun 2.80 TL'ye yükselmesiyle birlikte birçok işletme iflas etmiş işsizlik oranı \% 10.3'e çıkmıştır. 2018 yılı, Türkiye ekonomisi için yeni bir kriz yılı olmuştur. ABD ile yaşanan siyasal gerginliğin de etkisiyle dolar kuru 7 TL'ye çıkmış, enflasyon oranı son 15 yılın rekorunu kırarak \% 20.3 seviyesine çıkmıştır (Mazlum, 2020:57). Türkiye ekonomisi henüz kriz 
koşullarından tam olarak çıkamamışken 2020 yılında tüm dünyayı etkisi altına kalan pandemi, Mart ayından itibaren Türkiye'ye de sıçramış ve bütün dünya ekonomileri gibi Türkiye'yi de olumsuz etkilemiştir. Salgına karşı alınan önlemler nedeniyle ekonomik yaşam sekteye uğramış ve ekonomik dengeler alt üst olmuştur.

İncelenen dönemde dış ticaret de ekonomik krizlerle birlikte inişli çıkışlı bir dönem yaşamıştır. Döneme ait ihracat ve GSYİH verileri, Tablo 8'de özetlenmiştir.

Tablo 8. 2002-2020 arasında ihracat ve GSYİH verileri (Bin ABD Doları)

\begin{tabular}{|c|c|c|}
\hline YILLAR & İHRACAT & GSYİH \\
\hline 2002 & 36.059 .089 & 236.356 .165 \\
\hline 2003 & 47.252 .836 & 314.049 .410 \\
\hline 2004 & 63.167 .153 & 402.668 .845 \\
\hline 2005 & 73.476 .48 & 499.741 .069 \\
\hline 2006 & 85.534 .676 & 547.585 .958 \\
\hline 2007 & 107.271 .750 & 678.635 .566 \\
\hline 2008 & 132.027 .196 & 774.367 .681 \\
\hline 2009 & 102.142 .613 & 646.894 .531 \\
\hline 2010 & 113.883 .219 & 772.366 .615 \\
\hline 2011 & 134.906 .869 & 831.691 .448 \\
\hline 2012 & 152.461 .737 & 871.122 .993 \\
\hline 2013 & 151.802 .637 & 950.350 .602 \\
\hline 2014 & 157.610 .158 & 934.855 .430 \\
\hline 2015 & 143.838 .871 & 861.879 .256 \\
\hline 2016 & 142.529 .584 & 862.744 .469 \\
\hline 2017 & 156.992 .940 & 851.045 .500 \\
\hline 2018 & 167.920 .613 & 771.424 .856 \\
\hline 2019 & 171.454 .945 & 754.412 .685 \\
\hline 2020 & 171.464 .944 & 760.000 .000 (Tahmini) \\
\hline
\end{tabular}

Kaynak: TÜIK ve SBB

Tablo 8'den görüldüğü gibi hem GSYİH hem de ihracat, küresel kriz yılı olan 2009'da küçülmektedir. 2012 yılından itibaren ihracat değerleri inişli çıkışlı bir seyir izlemektedir. Oysa dönemin ilk yarısında, ihracat sürekli bir artış içindedir. GSYİH ise 2009 yılındaki 
daralmadan sonra döviz krizinin yaşandığı 2018 yılından itibaren kurdaki artışın etkisiyle daralma eğilimine girmişstir.

\section{LITERATÜR TARAMASI}

İhracata dayalı büyüme modellerinin birçok ülkede yaygınlaşmasıyla birlikte bu konudaki çalışmalar da artmıştır. Uluslararası alandaki çalışmalar 1970'li yıllara kadar gitmektedir. Michealy (1977) ve Balassa (1978), gelişmiş ülkeler üzerinde yaptıkları çalışmalarda iktisadi büyüme ile ihracat arasında pozitif ilişki bulmuşlardır.

Ekomonometrik yöntemlerin gelişmesiyle birlikte daha niceliksel analizler yapılabilmiştir. Marin (1992), yapmış olduğu çalışmada Granger nedensellik testini kullanarak Almanya, İngiltere, Japonya, ABD ekonomilerini incelemiş ve bu ülkeler için ihracata dayalı büyüme modelinin geçerli olmadığı sonucuna ulaşmıştır.

Ekanayake (1999), 8 Güney Asya ülkesi için ihracat ve büyüme ilişkisini EngleGranger eşbütünleşme ve Granger nedensellik analizi çerçevesinde incelemişler ve ülkelerin tamamında değişkenler arasında eşbütünleşme ilişkisi bulmuşlardır.

Anwer ve Sampath (2000), panel veri analizi ile yaptıkları çalışmada 96 ülkenin ihracat ile büyüme arasındaki ilişkilerini incelemişlerdir. Yapılan çalışmada 96 ülkeden sadece 8 tanesinde ihracata dayalı büyüme hipotezinin doğrulandığını belirlemişlerdir.

Konya (2004), yapmış olduğu çalışmada Granger nedensellik analizini kullanmış ve Lüksemburg, Danimarka, Hollanda, Yunanistan, Fransa, Norveç ve Macaristan için ihracat ile büyüme arasında nedensellik bulamamıştır. İzlanda, Avustralya, Avusturya, İrlanda için ihracattan büyümeye; Kanada, Japonya, Güney Kore, ABD, Portekiz, Finlandiya için büyümeden ihracata tek yönlü nedensellik tespit etmiştir.

Awokuse (2008), yine Granger nedensellik testini kullanarak yaptığı çalışmada, ihracatın büyümeyi etkilediği hipotezini reddeden sonuçlara varmıştır.

Biyase ve Zwane (2011), panel veri analizi kullanarak yaptığı çalışmada 30 Afrika ülkesi üzerinde çalışmış ve bu ülkelerde ihracata dayalı büyüme hipotezinin geçerliliğini saptamıştır.

Shan ve Jusoh (2012) Malezya üzerine yaptıkları çalışmada eşbütünleşme analizini kullanmışlar ve ihracata dayalı büyümeyi destekleyecek bulgulara ulaşmışlardır. 
Türkiye ekonomisi için yapılan çalışmalar genellikle ihracata dayalı büyüme modelinin benimsenmiş olduğu 1980 yılı sonrasını kapsamaktadır.

Çakmak ve Timurlenk (1995), Hsiao nedensellik testini kullanarak yaptıkları çalışmada Türkiye ekonomisi için ihracat ile iktisadi büyüme arasında herhangi bir nedensellik ilişkisi olmadığını saptamışlardır.

Doğanlar ve Fisunoğlu (1999), yaptıkları çalışmada Johansen eşbütünleşme analizini kullanmışlar ve ihracatın büyümeyi desteklediği sonucuna ulaşmışlardır.

Alıcı ve Ucal (2003), Toda Yamamoto nedensellik testini kullanarak yaptıkları çalışmada Türkiye ekonomisi için ihracattan büyümeye doğru bir nedensellik tespit etmişlerdir.

Şimşek (2003), çalışmasında Granger nedensellik testini kulanmış ve Türkiye için ihracattan büyümeye değil, ihracattan büyümeye doğru nedensellik ilişkisi bulmuştur.

Aktaş (2009), Johansen eşbütünleşme testi ve vektör hata düzeltme modelini kullanarak yaptığ çalışmada, Türkiye için ihracata dayalı büyüme modelinin kısa dönemde geçerli olduğu, uzun dönemde ise geçersiz olduğu sonucuna ulaşmıştır.

Takım (2010), yaptığı çalışmada Granger nedensellik testini kullanmış ve Türkiye ekonomisi için ihracatın büyümeyi desteklemediği sonucuna ulaşmıştır.

Altıntaş ve Çetintaş (2010), Granger nedensellik testi ile yaptıkları çalışmada ihracatın büyümeyi pozitif yönde etkilediği sonucuna varmışlardır.

Saraç (2013), doğrusal olmayan regresyon analiziyle çalışarak ihracatın bir dönem gecikmeli değerlerinin ekonomik büyümeyi pozitif yönde etkilediğini saptamıştır.

Aytaç (2017), çalışmasında VAR model ve Granger nedensellik analizi yöntemlerini kullanarak ihracattan büyümeye değil, büyümeden ihracata bir nedensellik tespit etmiştir.

Adıgüzel (2020), yapmış olduğu çalışmada kayan pencereler nedensellik analizini kullanmış ve ihracat büyüme ilişkisinin ancak son yıllarda ortaya çıktığı sonucuna ulaşmıştır.

Yukarıdaki literatür örneklerinden görüldüğü gibi ihracat ile GSYİH arasındaki ilişki hakkında fikir birliği olmayıp farklı çalışmalardan farklı sonuçlar çıkmıştır. Çalışmaların büyük bir çoğunluğu, Granger nedensellik testi ve Engle-Granger, Johansen eşbütünleşme 
testleri kullanılarak yapılmıştır. $\mathrm{Bu}$ çalışmada ise gerek birim kök testlerinde gerekse eşbütünleşme testinde yapısal kırılmaları da dikkate alan modeller kullanılmıştır.

\section{VERİ SETİ VE YÖNTEM}

Bu çalışmada 1923 ile 2019 yılları arasındaki dolar bazında ihracat ve GSYİH verileri kullanılmıştır. Değişkenler logaritmik değerleriyle analize tabi tutulmuştur. Birçok makroekonomik değişkenin düzey değerleri durağan değildir, bir başka deyişle birim köklüdür. Durağan olmayan zaman serileriyle yapılan regresyon analizlerinin anlamlı olabilmesi ve gerçek ilişkileri yansıtabilmesi, ancak bu zaman serileri arasında bir eşbütünleşme ilişkisinin varlığıyla mümkün olmaktadır (Gujarati, 1999:725). Aksi halde bir sahte regresyon durumu söz konusu olabilmektedir. İki farklı zaman serisi regresyon analizine tabi tutulduğunda aralarındaki ilişkinin gerçek mi sahte mi olduğunun bilinmesi gerekmektedir. $\mathrm{Bu}$ amaçla eşbütünleşme testlerine başvurulmaktadır. Bu çalışmada ihracat ve GSYİH ilişkisi araştırılırken Maki eşbütünleşme testinden faydalanılmıştır. Maki eşbütünleşme testinin uygulanabilmesi için değişkenlerin her birinin aynı mertebeden durağan olması gerekmektedir. Bu nedenle öncelikle değişkenlere ilişkin birim kök testleri yapılması gerekmektedir.

İktisadi zaman serileri ekonomik koşullara karşı duyarlı oldukları için, serilerde zaman içinde meydana gelebilecek yapısal değişikliklerin etkilerini dikkate almak önem arz etmektedir. Yapısal değişiklikleri dikkate almayan geleneksel birim kök testleri sapmalı sonuçlar verebilmektedir. Ayrıca zaman serilerinde zaman içinde içsel veya dışsal şoklardan kaynaklanan yapısal değişimlerin etkilerinin gözetilmesiyle gerçekleştirilen yapısal kırılmalı birim kök testleriyle, durağan olmayan serilerin durağan özellikler sergileyebileceği belirlenebilmektedir (Perron, 1989:1361-1363). Bu sakıncaları önlemek adına bu çalışmada Narayan ve Popp (2010) yapısal kırılmalı birim kök testi kullanılmıştır. Narayan ve Popp birim kök testinde durağanlık analizi aşağıdaki regresyon denklemlerine dayanmaktadır:

$d_{t}^{M 1}=\propto+\beta t+\varphi^{*}(L)\left(\theta_{1} D U_{1, t}^{\prime}+\theta_{2} D U_{2, t}^{\prime}\right)$

$d_{t}^{M 2}=\alpha+\beta t+\varphi^{*}(L)\left(\theta_{1} D U_{1, t}^{\prime}+\theta_{2} D U_{2, t}^{\prime}+\gamma_{1} D T_{1, t}^{\prime}+\gamma_{2} D T_{2, t}^{\prime}\right)$

Burada, (i=1,2 olmak üzere) $D U_{i, t}^{\prime}=1\left(t>T_{B, i}^{\prime}\right)$, sabitteki, $D T_{i, t}^{\prime}=1\left(t>T_{B, i}^{\prime}\right)(t-$ $\left.T_{B, i}^{\prime}\right)$, trenddeki yapısal kırılmaları gösterirken $\left(T_{B, i}^{\prime}\right)$ ise serilerde meydana gelen yapısal kırılmaların tarihlerini göstermektedir (Narayan ve Popp, 2010:1426). Denklemdeki $\theta_{i}$ ve $\gamma_{i}$ 
parametreleri, sabitteki ve trenddeki yapısal kırılmaların büyüklüğünü ifade etmektedir. $\left[\varphi^{*}(L)\right]$ ise serilerde meydana gelen yapısal kırılmaların zaman içinde yavaş bir şekilde gerçekleşmesini olanaklı kılmaktadır (Narayan ve Popp, 2010: 1426-1428). Narayan ve Popp birim kök testinin boş hipotezi, serinin birim köklü olduğu şeklindedir. Hesaplanan test istatistikleri, kritik tablo değerlerinden mutlak değer olarak büyükse, temel hipotez reddedilmekte ve serinin durağan olduğu sonucuna ulaşılmaktadır. Narayan ve Popp testi, iki kırılmayı dikkate almakta ve yapısında hem M1 hem de M2 modellerine göre istatistikler hesaplanmaktadır. Çalışmada GSYİH ve ihracat serilerinin her ikisi de düzeyde birim köklü olarak bulunmuş, birinci farkları alındığında durağan hale gelmişlerdir. Bir başka deyişle her iki seri de I(1) olarak bulunmuştur. Serilerin I(1) olması durumunda Maki eşbütünleşme testinin yapılması uygun olmaktadir.

Analiz edilen serilerde yapısal kırılmaların varlığı durumunda eşbütünleşme testlerinin de yapısal kırılmalı bir şekilde uygulanması önem arz etmektedir. Maki (2012) tarafından geliştirilen eşbütünleşme testi, beş yapısal kırılmaya kadar seriler arasında eşbütünleşmenin varlığını araştırabilmektedir. Maki, dört farklı test istatistiği geliştirmiştir (Maki, 2012:1,2):

$y_{t}=\mu+\sum_{i=1}^{k} \mu_{i} D_{i, t}+\beta^{\prime} x_{t}+u_{t}$

$y_{t}=\mu+\sum_{i=1}^{k} \mu_{i} D_{i, t}+\beta^{\prime} x_{t}+\sum_{i=1}^{k} \beta_{i}^{\prime} x_{t} D_{i, t}+u_{t}$

$y_{t}=\mu+\sum_{i=1}^{k} \mu_{i} D_{i, t}+\gamma t+\beta^{\prime} x_{t}+\sum_{i=1}^{k} \beta_{i}^{\prime} x_{t} D_{i, t}+u_{t}$

$y_{t}=\mu+\sum_{i=1}^{k} \mu_{i} D_{i, t}+\gamma t+\sum_{i=1}^{k} \gamma_{i} t D_{i, t}+\beta^{\prime} x_{t}+\sum_{i=1}^{k} \beta_{i}^{\prime} x_{t} D_{i, t}+u_{t}$

3 numaralı denklem, model 0 olarak adlandırılmakta ve sabit terimde kırılmaya izin veren trendsiz modeli ifade etmektedir. 4 numaralı denklem model 1 adını almakta ve sabit terimde ve eğimde kırılmaya izin veren trendsiz modeli göstermektedir. 5 numaralı denklem, model 2 olarak ifade edilmekte, sabit terimde ve eğimde kırılmaya izin veren trendli modeli göstermektedir. Son olarak 6 numaralı denklem ise model 3 olarak isimlendirilmekte ve sabit terimde, eğimde ve trendde kırılmaya izin vermektedir. Denklemlerde boş hipotez, yapısal kırılma altında eşbütünleşme ilişkisi olmadığını belirtmektedir (Maki, 2012:2-4). Hesaplanan test istatistikleri, kritik değerlerden daha küçük olması durumunda boş hipotez reddedilmekte, bir başka deyişle seriler arasında bir eşbütünleşme ilişkisi olduğu sonucuna ulaşılmaktadır. 


\section{BULGULAR}

Öncelikle her iki seri için birim kök testleri yapılmıştır. Narayan ve Popp yapısal kırılmalı birim kök test sonuçları, Tablo 9'da özetlenmiştir.

Tablo 9. Narayan ve Popp yapısal kırılmalı birim kök testi sonuçları

\begin{tabular}{|l|l|l|l|l|}
\hline & GSYIH M1 & GSYİH M2 & IHRACAT M1 & IHRACAT M2 \\
\hline Birinci Kırılma & $45-45-0.4639$ & $45-45-0.4639$ & $33-33-0.3402$ & $33-33-0.3402$ \\
\hline İkinci Kırılma & $61-61-0.6289$ & $61-61-0.6289$ & $39-39-0.4021$ & $39-39-0.4021$ \\
\hline phi= rho-1 & -0.4451 & -0.4354 & -0.4899 & -0.7175 \\
\hline $\mathbf{t}$ istatistiği & -2.963 & -2.868 & -2.106 & -2.842 \\
\hline Optimal Gecikme & 1.000 & 1.000 & 3.000 & 3.000 \\
\hline
\end{tabular}

Test istatistiğinin karşılaştırılacağ 1 kritik değerler ise Tablo 10'da verilmiştir.

Tablo 10. Narayan ve Popp birim kök testi kritik değerler

\begin{tabular}{|c|c|c|c|c|c|c|}
\hline & \multicolumn{3}{|l|}{ M1 } & \multicolumn{3}{|l|}{ M2 } \\
\hline $\mathbf{T}$ & $\% 1$ & $\% 5$ & $\% 10$ & $\% 1$ & $\% 5$ & $\% 10$ \\
\hline 50 & -5.259 & -4.514 & -4.143 & -5.949 & -5.181 & -4.789 \\
\hline 100 & -4.958 & -4.316 & -3.980 & $\begin{array}{l}-5.576 \\
\end{array}$ & -4.937 & -4.596 \\
\hline 300 & -4.731 & -4.136 & -3.825 & -5.318 & -4.741 & -4.430 \\
\hline 500 & -4.672 & -4.081 & -3.772 & -5.287 & -4.692 & -4.396 \\
\hline
\end{tabular}

Kaynak: Narayan ve Popp (2010:1429)

Narayan ve Popp birim kök testi, Gauss kodu kullanılarak yapılmıştır. GSYİH değişkenine ilişkin verilerde birinci kırılma 45. gözleme, ikinci kırılma ise 61. gözleme denk gelmektedir. Veri periyodu dikkate alındığında kırılma tarihleri sırasıyla 1967 ve 1983 yıllarına işaret etmektedir. İlgili kırılma tarihleri, planlı ekonomi ve liberal dönemin politikaları arasında bir karşılaştırma yapmak açısından önem arz etmektedir. M1 modeli için t istatistiği, -2.963 olarak bulunmuştur. $\mathrm{Bu}$ değerin kritik değerlerle karşılaştırılması gerekmektedir. Kritik değer tablosundaki $\mathrm{T}$ değeri, uygulamanın gözlem sayısını ifade etmektedir. GSYİH verilerinde 97 gözlem olduğundan en yakın olarak 100 gözleme ilişkin kritik değerler kullanılmıştır. -2.963 değeri, \% 1, \% 5 ve \% 10 anlamlılık düzeyinde kritik değerlerden $(-4.958,-4.316,-3.980)$ daha büyük olduğundan GSYİH serisinin birim köklü olduğu sonucuna varılmıştır. M2 modeli incelendiğinde kırılma tarihleri yine 1967 ve 1983 yılları olarak bulunmuştur. M2 modeli için test istatistiği, -2.868 olarak hesaplanmıştır. $\mathrm{Bu}$ 
değerin de Tablo 10'daki M2 kısmına denk gelen kritik değerlerle karşılaştırılması gerekmektedir. -2.868 değeri, \% 1, \% 5 ve \% 10 anlamlılık düzeylerinde kritik değerlerden ($5.576,-4.937,-4.596$ ) büyük olduğundan GSYİH serisinin yine birim köklü olduğu sonucuna ulaşılmıştır. İhracat serisi için de aynı uygulamalar yapılmış, M1 ve M2 modelleri için test istatistikleri sırasıyla, -2.106 ve -2.842 olarak hesaplanmıştır. Her iki modele ait test istatistikleri, Tablo 10'daki kritik değerlerle karşılaştırılmış ve ihracat serisinin de birim kök içerdiği tespit edilmiştir. Ardından her iki serinin birinci farkları alınarak birim kök testi tekrarlanmıştır. Fark değerlerine ilişkin test sonuçları Tablo 11'de özetlenmiştir.

Tablo 11. Narayan ve Popp yapısal kırılmalı birim kök testi sonuçları

\begin{tabular}{|l|l|l|l|l|}
\hline & GSYİ M1 & GSYIH M2 & IHRACAT M1 & IHRACAT M2 \\
\hline Birinci Kırılma & $36-36-0.3750$ & $36-36-0.3750$ & $34-34-0.3542$ & $34-34-0.3542$ \\
\hline İkinci Kırılma & $38-38-0.3958$ & $39-39-0.4063$ & $36-36-0.3750$ & $57-57-0.5938$ \\
\hline phi= rho-1 & -0.7760 & -0.8054 & -0.8813 & -1.027 \\
\hline t istatistiği & -7.371 & -7.946 & -8.368 & -10.07 \\
\hline Optimal Gecikme & 0.0000 & 0.0000 & 0.0000 & 0.0000 \\
\hline
\end{tabular}

Tablo 11'den görüldüğü gibi birinci fark1 alınmış GSYİH değerlerine ait serinin M1 ve M2 modellerine ilişkin test istatistikleri, sırasıyla -7.371 ve -7.496 olarak hesaplanmıştır. $\mathrm{Bu}$ değerler Tablo 10'daki kritik değerlerle karşılaştırıldığında, \% 1, \% 5 ve \% 10 anlamlılık düzeylerinde kritik değerlerden daha küçük olduğu görülmektedir. $\mathrm{Bu}$ durumda birinci fark1 alınmış GSYİH serisinin durağan olduğu sonucuna ulaşılmıştır. Birinci farkı alınmış ihracat serisinin M1 ve M2 modellerine ilişkin test istatistikleri ise sırasıyla, -8.368 ve -10.07 olarak hesaplanmıştır. Bu değerler de Tablo 9'daki kritik değerlerle karşılaştırıldığında \% 1, \% 5 ve \% 10 anlamlılık düzeylerinde kritik değerlerden daha küçük olduğu görülmektedir. Böylece birinci farkı alınmış ihracat serisinin de durağan olduğu anlaşılmıştır.

Yapılan birim kök analizlerinde her iki serinin de düzey değerlerinde durağan olmadıkları, birinci farkları alındığında ise durağan hale geldikleri tespit edilmiştir. Bir başka deyişle her iki seri de I(1) olarak belirlenmiştir. Serilerin I(1) olması, Maki eşbütünleşme testinin yapılabilmesine olanak vermektedir. Maki eşbütünleşme testinin sonuçları dört ayrı model olarak Tablo 12, 13, 14 ve 15'de verilmiştir. Uygulama Gauss kodu kullanarak yapılmıştır. 
Tablo 12. Maki eşbütünleşme testi model 0 sonuçları

\begin{tabular}{|l|l|l|l|l|l|}
\hline & 5 Kirılma & 4 Kirılma & 3 Kirılma & 2 Kirılma & 1 Kırılma \\
\hline bp1 & 56 & 56 & 56 & 56 & 56 \\
\hline bp2 & 37 & 37 & 37 & 37 & \\
\hline bp3 & 72 & 72 & 72 & & \\
\hline bp4 & 79 & 39 & & & \\
\hline bp5 & 85 & & & & -3.854622 \\
\hline t istatistiği & -5.1321882 & -5.1321882 & -5.1321882 & -3.854622 & \\
\hline
\end{tabular}

Tablo 13. Maki eşbütünleşme testi model 1 sonuçları

\begin{tabular}{|l|l|l|l|l|l|}
\hline & 5 Kırılma & 4 Kırılma & 3 Kırılma & 2 Kırılma & 1 Kırılma \\
\hline bp1 & 36 & 36 & 36 & 36 & 36 \\
\hline bp2 & 75 & 75 & 75 & 75 & \\
\hline bp3 & 9 & 9 & 9 & & \\
\hline bp4 & 24 & 24 & & & \\
\hline bp5 & 31 & & & & -4.3118711 \\
\hline t istatistiği & -5.1279783 & -5.1279783 & -5.1279783 & -5.1279783 & \\
\hline
\end{tabular}

Tablo 14. Maki eşbütünleşme testi model 2 sonuçları

\begin{tabular}{|l|l|l|l|l|l|}
\hline & 5 Kırılma & 4 Kırılma & 3 Kırılma & 2 Kırılma & 1 Kırılma \\
\hline bp1 & 26 & 26 & 26 & 26 & 26 \\
\hline bp2 & 37 & 37 & 37 & 37 & \\
\hline bp3 & 43 & 43 & 43 & & \\
\hline bp4 & 91 & 91 & & & \\
\hline bp5 & 85 & & & & -4.0862219 \\
\hline $\mathbf{t}$ istatistiği & -5.439453 & -4.7301384 & -4.5653114 & -4.538121 & \\
\hline
\end{tabular}


Tablo 15. Maki eşbütünleşme testi model 3 sonuçları

\begin{tabular}{|l|l|l|l|l|l|}
\hline & 5 Kırılma & 4 Kurılma & 3 Kırılma & 2 Kırılma & 1 Kırılma \\
\hline bp1 & 27 & 27 & 27 & 27 & 27 \\
\hline bp2 & 91 & 91 & 91 & 91 & \\
\hline bp3 & 41 & 41 & 41 & & \\
\hline bp4 & 80 & 80 & & & \\
\hline bp5 & 74 & & & & \\
\hline $\mathbf{t}$ istatistiği & -6.6149374 & -6.4483429 & -6.2519956 & -5.9344233 & -5.9344233 \\
\hline
\end{tabular}

Maki tarafından geliştirilen eşbütünleşme testinde kırılma sayıları ve değişken sayılarına göre değişen kritik değerler belirlenmiştir (Maki, 2012:3). Modellerde hesaplanan test istatistiklerinin kritik değerlerle karşılaştırılması gerekmektedir. Eğer test istatistiği, kritik değerden büyükse seriler arasında bir eşbütünleşme olmadığı sonucuna varılmaktadır. Tablo $11,12,13,14$ 'te yer alan tüm modeller $\% 1, \% 5$ ve \% 10 anlamlılık düzeylerinde bütün kırılma sayılarında incelendiğinde hepsinde test istatistiğinin kritik değerlerden büyük olduğu görülmektedir. Örneğin Model 3'de 5 kırılma dikkate alınarak yapılan test sonucunda test istatistiği -6.6149374 olarak hesaplanmıştır. Bu değer, kritik değerlerle (-8.713, -8.129, 7.811) karşılaştırıldığında \% 1, \% 5 ve \% 10 anlamlılık düzeylerinde test istatistiğginin kritik değerlerden daha büyük olduğu anlaşılmaktadır. Diğer modeller ve kırılma sayıları için aynı işlem tekrarlandığında aynı durumun geçerli olduğu görülmektedir.

$\mathrm{Bu}$ durumda, yapılan Maki testinde GSYİH serisi ile ihracat serisi arasında bir eşbütünleşme ilişkisi bulunamamıştır. Bir başka deyişle, Türkiye ekonomisi için GSYİH ile ihracat arasında bir uzun dönem ilişkisi tespit edilememiştir.

\section{SONUÇ}

$\mathrm{Bu}$ çalışmada ihracata dayalı büyüme modelinin Türkiye ekonomisi için geçerliliği analiz edilmiştir. $\mathrm{Bu}$ çerçevede cumhuriyet öncesi dönemden başlayarak uygulanan ekonomik politikalar bağlamında ihracatın gelişimi incelenmiştir. Osmanlı imparatorluğu, merkantilizm ve sanayi devrimi süreçlerine dahil olamadığı için iktisadi anlamda Avrupa'nın gerisinde kalmış ve cumhuriyete sağlam bir ekonomi miras bırakamamıştır. Cumhuriyetin ilk dönemlerinde Osmanlı'dan kalan yapının etkili olduğu görülmektedir. $\mathrm{Bu}$ dönemde sanayileşme alanında yetersiz kalınması ve dolayısıyla ihracatın gelişmemesinde Osmanlı'dan 
kalma ticaret anlaşmalarının gümrük vergisi gibi bazı hükümlerinin Lozan Antlaşması aracılığıyla devam ettirilmesinde önemli bir payı olduğu görülmektedir. Daha sonraki dönemlerde ise bazı dönemler daha devletçi, bazı dönemler daha liberal politikalar uygulanmış, ihracat da bu politikalara göre şekillenmiştir. Devletçi dönemde sanayileşme ve kalkınma çabaları ön plandayken 1950 yılından sonra liberal ekonomi politikaları hedeflenmiştir. Ancak uygulamada liberalleşme gerçekleşmemiş, özellikle diş ticaret kontrolleri anlamında devletin ekonomiye müdahalesi devam etmiştir. 1960 ve 1970'li y1llar, ithal ikameci politikalar ve planlı ekonomi anlayışının öne çıktığı yıllar olmuştur. İthal ikameci politikalar nedeniyle sanayinin ithalat bağımlılığının artması, ihracat artışı ile dengelenmeye çalışılmış, ancak bu alanda hedeflenen düzeye ulaşılamamıştır. Buna rağmen, planlı dönemde yüksek bir büyüme hızı devam ettirilebilmiştir. 1980 sonrası ise Türkiye ekonomisi, tekrar bir liberalleşme sürecine girmiş ve büyüme modeli olarak ihracata dayalı büyüme modeli benimsenmiştir. Liberalleşme politikalarının en başarılı olduğu alan da ihracat alanında olmuştur. 1980 sonrasında, ihracat anlamında olumlu bir seyir izlense de finansal krizlerin de başladığı bir döneme girilmiştir. 1994 ve 2001 yıllarında yaşanan finansal krizler ve 2008 yılındaki küresel krizin Türkiye'deki etkileri nedeniyle Türkiye ekonomisinin kırılganlıkları artış göstermiştir. Bu çalışmada dönemler itibariyle ihracatın GSYİH üzerindeki etkilerinin ipuçları aranmıştır. Özellikle planlı dönemde ve 1980 sonrası dönemde ihracat ve GSYİH'nin birlikte hareket etmediği verilerden gözlemlenmiştir.

Çalışmanın ekonometrik bölümünde ise ihracat ve GSYİH serileri eşbütünleşme analizi yapılmıştır. Eşbütünleşme testi, yapısal kırılmaları da dikkate alan Maki testi ile yapılmıştır. Test sonucunda ihracat ve GSYİH arasında uzun dönemli bir ilişki tespit edilememiştir. Bir başka ifadeyle Türkiye ekonomisi açısından ihracata dayalı büyüme tezi geçerli değildir. Literatür taramasında görüldüğü gibi, bazı ülkeler için ihracata dayalı büyüme tezi geçerliyken bazılarında geçerli olamamaktadır. Güney Asya ülkeleri için geçerli olduğu halde, Avrupa ülkelerinin bir kısmında ihracata dayalı büyüme tezinin geçerli olmadığı, yapılan çalışmalarda gösterilmiştir. Bu çalışmalar, ülkelerin ihracat politikalarının oluşturulmasında önem arz etmektedir. Türkiye için de uzun dönem verileriyle çalışıldığında bu hipotezin geçerli olmadığı bu çalışmayla saptanmıştır. Ancak böyle bir sonuca ulaşılmış olması Türkiye ekonomisi için ihracatın önemli olmadığı anlamına gelmemelidir. İhracatın ekonomik büyümeyi destekleyecek şekilde düzenlenmesi gerektiği sonucunu çıkarmak daha doğrudur. Ayrıca ekonomik büyüme politikaları yapılırken büyümenin ihracat dışındaki kaynaklarına daha fazla önem verilmesi gerektiği de bu çalışmanın çıktılarından biridir. 
Sanayi sektörünün üretimine devam edebilmek için ihtiyaç duyduğu girdilerin finansmanı açısından da ihracat önem arz etmektedir. Ayrıca Türkiye ekonomisinin ithalat yapısı da çoğunlukla ithal girdilerden oluşmaktadır. Yapılan çalışmalardan, ihraç edilen ürünler içinde ithal girdi oranının \% 65 civarında olduğu bilinmektedir. Bu bağlamda ihracattaki gelişimin ithalattaki gelişimin gerisinde kalması, bir başka ifadeyle ithalatın ihracatla finanse edilememesi, ilerleyen yıllarda finans kapitale daha fazla bağımlılığa sebep olacaktır. Bu nedenle ihracata bir büyüme kaynağı olarak bakmak yerine finansman aracı olarak değerlendirmek daha yerinde olacaktır.

\section{KAYNAKÇA}

Adıgüzel, U. (2020). Türkiye'de ihracat - büyüme ilişkisi: Ampirik bir analiz, Journal of International Management Educational and Economics Perspectives, 8 (2), 154-165.

Alıcı, A.A \& Ucal, M. Ş. (2003). Foreign direct investment, exports and output growth of Turkey: Causality analysis. European Trade Study Group (ETSG) Fifth Annual Conference, (September), Madrid

Altıntaş, H. \& Çetintaş, H. (2010). Türkiye'de ekonomik büyüme, beşeri sermaye ve ihracat arasındaki ilişkilerin ekonometrik analizi: 1970- 2007, Erciyes Üniversitesi İktisadi ve İdari Bilimler Fakültesi Dergisi, 36, 33-56.

Anwer, M. S. \& Sampath, R. K. (2000). Exports and economic growth, Indian Economic Journal, 47(3), 79-88.

Altınoğlu, E. \& Güloğlu, B. (2002). Finansal serbestleşme politikaları ve finansal krizler, İstanbul Üniversitesi Siyasal Bilgiler Fakültesi Dergisi, 27

Awokuse, T. O. (2008). Trade openness and economic growth: Is growth export-led or importled?. Applied Economics, 40(2), 161-173.

Aydın, A. (2019). Türkiye ekonomisinde 1990 sonrası ekonomik krizlerin sonuçları bakımından değerlendirilmesi, Yayınlanmamış yüksek lisans tezi, İstanbul Teknik Üniversitesi, İstanbul.

Aytaç, A. (2017). Ekonomik büyüme - ihracat ilişkisi: 2001-2016 Türkiye örneği. Sosyal Bilimler Araştırma Dergisi, 6 (4) , 214-222.

Balassa, B. (1978). Exports and economic growth: further evidence. Journal of Development Economics, 5, 181-9

Balkanlı, A. Osman (2002). Küresel ekonominin belirleyici faktörleri üzerine, Uludă̆ Üniversitesi İktisadi İdari Bilimler Fakültesi Dergisi, 21(1), 13-26.

Baskıc1, M. M. (2005). 1800-1914 Yıllarında Anadolu'da İktisadi Değişim. Ankara: Turhan Kitabevi.

Berkes, N. (2013). Türkiye İktisat Tarihi, İstanbul: Yapı Kredi Yayınları.

Biyase, M. \& Zwane, T. (2011). An Export-Led Growth (ELG) Paradigm in Africa: Panel Data Approach. ESSA 2011 Biennial Conference of the Economic Society of South Africa, 5-7 September 2011. 
Boratav, K. (2015). Türkiye İktisat Tarihi, Ankara: İmge Kitabevi.

Buluş, A. \& Mercan, B. (2002). Son dönem Osmanlı iktisat politikaları. Liberal Düşünce, Güz(28), 247-256.

Cem, İ. (1989). Türkiye'de Geri Kalmışlı̆̆ın Tarihi, İstanbul: Doğan Ofset.

Coşar, N. (1995). Denk Bütçe-Sağlam Para Politikası ve Devletçilik 1924-1938, İstanbul: Bağlam Yayıncilık.

Çadırcı, M. (1991). Tanzimat Döneminde Anadolu Kentlerinin Sosyal ve Ekonomik Yapıları, Ankara: Türk Tarih Kurumu Yayınları

Çakmak, E. \& Temurlenk, M.S. (1995). Causality relationship between export expansion and economic growth: empirical evidence for Turkey, Ankara Üniversitesi Siyasal Bilgiler Fakültesi Dergisi, 50(1- 2), 129-143.

Çavdar, T. (2004). Türkiye'nin Demokrasi Tarihi (1950’den Günümüze). Ankara: İmge Kitabevi Yayınları.

Develi, A. \& Özdoğan, F. (2020). İktisat politikaları Çerçevesinde Tek Parti Dönemi Hükümet Programlarında Sosyal Politika Hedefleri (1923-1939), Uluslararası Anadolu Sosyal Bilimler Dergisi.

Doğanlar, M \& Fisunoğlu, M. (1999). Causality between exports and economic growth in Asian Countries. Yapı Kredi Economic Review, 10(11), 3-11

Dokuyan, S. (2014), Savaş ekonomisi ve varlık vergisi üzerine bir değerlendirme, Eskişehir Osmangazi Üniversitesi Sosyal Bilimler Dergisi, 15(2), 23-55

Dura, C. \& Altıparmak, A. (2000). 1838 Osmanlı İngiliz ticaret antlaşması: Nedenleri ve sonuçları. Erciyes Üniversitesi İktisadi ve İdari Bilimler Fakültesi Dergisi(16), 17-30.

Duru, B. (2008). Açıklamalı yönetim zamandizini, Ankara Üniversitesi Siyasal Bilgiler Fakültesi Kamu Yönetimi Araştırma ve Uygulama Merkezi: 3; Türkiye Cumhuriyeti İdare Tarihi Araştırmast, Ankara

Ekanayake, E. M. (1999). Exports and economic growth in Asian developing countries: cointegration and error-correction models, Journal of Economic Development, 24(2): 43-56

Gomes, L. (1987). Foreign Trade and The National Economy: Mercantilist and Classical Perspectives, London: Macmillian Press.

Gökçen, A.M. (1998). Cumhuriyet Döneminde İktisadi Gelişme, Yeni Türkiye Dergisi, Sayl:23-24, Cumhuriyet Özel Sayısı V, 3255-3269.

Güner, A.O. (1978). Türkiye'nin Kalkınması ve İktisadi Devlet Teşekkülleri, İstanbul: Damla Yayınevi.

Gürsoy, B. (1984). 100. Yılında Düyun-u Umumiye İdaresi Üzerinde Bir Değerlendirme, Ístanbul Üniversitesi İktisat Fakültesi, Ord. Prof. Şükrü Baban'a Armă̆an, İstanbul.

Hafter, D. M. (1964) Critics of Mercantilism in France: 1751-1789: The Industrial Reformers. Yayınlanmamış doktora tezi. Yale University, New Haven.

İnalcık, H. (2000) Imtiyâzât. İslam Ansiklopedisi (C.22, ss.245-252). Türkiye Diyanet Vakfi, İstanbul

Karluk, S. R. (2005). Cumhuriyetin İlanından Günümüze Türkiye Ekonomisinde Yapısal Dönüşüm (10. Baskı). İstanbul: Beta Yayınları. 
Kazgan, G. (1999). Tanzimat'tan 21. yüzylla Türkiye ekonomisi, İstanbul: İstanbul Bilgi Üniversitesi Yayınları.

Kazgan, H. (1981). Sanayi Tarihi, İstanbul: İTÜ Matbaas1.

Kepenek, Y. \& Yentürk, N. (2001). Türkiye Ekonomisi (12. Bask1). İstanbul: Remzi Kitabevi.

Kılıçbay, A. (1997). Türkiye'nin Ekonomi Politikaları (1930-1996 ve sonrası), İstanbul: Der yayınlar1.

Koçak, C. (1986). Türkiye'de Milli Şef dönemi (1938-1945). Ankara: Yurt Yayınları.

Konya, L. (2004). Export-led growth, growth-driven export, both or none? granger causality analysis on OECD countries, applied econometrics and international development, 4(1), 73 94.

Koraltürk, M. ve Çetin, C. (2013). Türkiye'de Liberal İktisadi Düşünce, İstanbul: İletişim Yayinlar1.

Kutay, C. (1939). Celal Bayar (cilt 1). İstanbul: Kenan Basımevi.

Maki, D. (2012). Tests for cointegration allowing for an unknown number of breaks, Economic Modelling, 29(5).

Mango, A. (2007). Atatürk Modern Türkiye’nin Kurucusu, İstanbul: Remzi Kitabevi.

Marin, D. (1992) Is the export-led hypothesis valid for industrialised countries?. Review of Economics and Statistics, 74(4), 678-688.

Mazlum, N. (2020). 1980-2018 dönemi Türkiye ekonomisi ve dış ticaretinin gelişim seyri, Gümrük ve Ticaret Dergisi, 7(22)

Memiş, Ş. (2020). 20. Yüzyıl Türkiye Ekonomisi Üzerine Kısa Bir Analiz (1923-2000), Dumlupinar Üniversitesi Sosyal Bilimler Dergisi

Michaely, M. (1977). Exports and growth: An empirical investigation, Journal of Economic Development, 4: 49- 53

Müderrisoğlu, A. (1981). Atatürk'ün Mali Dehası Tekâlif-i Milliye, Maliye Dergisi Atatürk Özel Saylsi.

Narayan, P.K. ve Popp, S. (2010). A new unit root test with two structural breaks in level and slope at unknown time, Journal of Applied Statistics, 37(9), 1425-1438.

Öner, E. (2005). Osmanlı imparatorluğu ve Cumhuriyet Döneminde Mali İdare, Ankara: T.C. Maliye Bakanlığı APK Başkanlığı Yayını.

Özatay, F. (2009). Finansal Krizler ve Türkiye, İstanbul: Doğan Kitap.

Özcan, H.A. (1998). 'Dünden Bugüne Dış Ticaretimizdeki Gelişmeler', Dış Ticaret Dergisi, Sayl: Özel Sayl, 41-76.

Pamir, A. (2002). Kapitülasyon kavramı ve Osmanlı Devleti’ne etkileri, Ankara Üniversitesi, Hukuk Fakültesi Dergisi, 51, 2

Pamuk, Ş. (2009). Osmanlıdan Cumhuriyete Küreselleşme, Ikktisat Politikalarl ve Büyüme (Seçme Eserleri II) (2 b.). İstanbul: Türkiye İş Bankası Kültür Yayınları.

Pamuk, Ş. (2015). Osmanlı-Türkiye İktisadî Tarihi 1500-1914, İstanbul: İletişim Yayınları.

Parasız, İ. (1998). Türkiye Ekonomisi, 1923'den Günümüze İktisat ve İstikrar Politikalarl, Bursa: Ezgi Kitabevi Yayınları. 
Perron, P. (1989). The great crash, the oil price shock, and the unit root hypothesis, Econometrica, 57(6), 361-1401.

Saraç, T. B. (2013). İhracat ve ithalatın ekonomik büyüme üzerindeki etkisi: Türkiye örneği, Ege Akademik Baklş, 13(2), 181-194.

Sarıbay, A.Y. (1986). Kemalist Ideolojide Modernleşmenin Anlamı: Sosyo-Ekonomik Bir Çözümleme Denemesi, İstanbul: İ.Ü. İktisat Fakültesi Yayınları.

Sayar, N.S. (1977). Türkiye Imparatorluk Dönemi Mali Olaylarl, İstanbul: Met-Er Matbaas1.

SBB (2018). TUIK Verilerine Göre Uyumlaştırılmış Gayri Safi Yurt Iç̧i Hasıla.

Shan, L. H. \& Jusoh, Z. (2012). Is the export-led growth hypothesis valid for Malaysia?. Statistics Malaysia Journal of the Department of Statistics, 2, 1-14.

Şahin, H. (2006). Türkiye Ekonomisi, Bursa: Ezgi Kitabevi.

Şimşek, M. (2003). İhracata Dayalı Büyüme Hipotezinin Türkiye Ekonomisi Verileri ile Analizi, 1960-2002, D.E.Ü. I.I.B.F. Dergisi, 18(2), 43-63

Takım, A. (2010). Türkiye'de GSYİH ile İhracat Araındaki İlişki: Granger Nedensellik Testi, Atatürk Üniversitesi Sosyal Bilimler Enstitüsü Dergisi, 14(2), 1-16

Takım, A. (2012). Demokrat Parti Döneminde Uygulanan Ekonomi Politikaları ve Sonuçları, Ankara Üniversitesi, SBF Dergisi, 67(2).

Taşar, M. (2010). Türkiye'nin güçlü ekonomiye geçiş programı ve makroekonomik etkilerinin analizi, Niğde Üniversitesi İktisadi İdari Bilimler Fakültesi Dergisi, 3(1).

Taşkın, M. M. (2003) 1923-2003 döneminde Türkiye Cumhuriyeti'nin dış ticaret politikaları, Dış Ticaret Dergisi, Özel Sayl, 131-152

TUIK (2020). Yıllara Göre Dış Ticaret. Erişim tarihi: 31 Ağustos 2020, www.tuik.gov.tr

Türkcan, E. (2009). Dünya'da ve Türkiye'de Bilim, Teknoloji ve Politika, İstanbul: İstanbul Bilgi Üniversitesi Yayınları.

Wallerstein, I. (2011). Modern Dünya Sistemi III. (L. Boyacı, Çev.) İstanbul: Yarın Yayincilik.

Yeşilyurt, Ş. (2016). Varlık Vergisi Hakkında Bir Değerlendirme, Uluslararası Yönetim Íktisat ve İsletme Dergisi, Cilt 12, Sayı 27

Yeldan, E.(2001). Küreselleşme Sürecinde Türkiye Ekonomisi, İstanbul: İletişim Yayınları. 